Portland State University

PDXScholar

Institute for Sustainable Solutions Publications

and Presentations

Institute for Sustainable Solutions

February 1990

\title{
Modeling coastal landscape dynamics
}

Robert Costanza

Portland State University

Fred Hal Sklar

Mary L. White

Follow this and additional works at: https://pdxscholar.library.pdx.edu/iss_pub

Part of the Sustainability Commons

Let us know how access to this document benefits you.

\section{Citation Details}

Costanza, R., F. H. Sklar, and M. L. White. 1990. Modeling coastal landscape dynamics. BioScience 40:91-107.

This Article is brought to you for free and open access. It has been accepted for inclusion in Institute for Sustainable Solutions Publications and Presentations by an authorized administrator of PDXScholar. Please contact us if we can make this document more accessible: pdxscholar@pdx.edu. 


\title{
Modeling Coastal Landscape Dynamics

\author{
Process-based dynamic spatial ecosystem simulation can \\ examine long-term natural changes and human impacts
}

\author{
Robert Costanza, Fred H. Sklar, and Mary L. White
}

$\mathbf{P}$ redicting the way ecological systems respond to human modifications has been a primary goal of ecosystem ecology (Hall and DeAngelis 1985). Ecosystems represent an economic resource whose value to society is only now becoming recognized. Coastal ecosystems in particular provide valuable marketed and nonmarketed services, including fish and wildlife resources, storm protection, and recreation. The average value to society of coastal wetlands has been estimated as \$2000-\$10,000/acre, even though their market price is only $\$ 200$ $\$ 400$ /acre (Costanza et al. in press, Farber and Costanza 1987, Turner et al. 1988).

Coastal ecosystems are being threatened by a host of human activities, including oil and gas exploration, urban development, and sediment diversion. The potential for sea level rise due to global greenhouseeffect warming is also of concern. Protecting and preserving these ecosystems requires the ability to predict the direct and indirect, temporal, and

Robert Costanza is an associate professor in the Coastal and Environmental Policy Program, Chesapeake Biological Laboratory, Center for Environmental and Estuarine Studies, University of Maryland, Solomons, MD 20688-0038. Fred H. Sklar is an assistant professor at the Belle Baruch Institute, University of South Carolina, Columbia, SC 29211. Mary L. White is a research associate at the Coastal Ecology Institute, Center for Wetland Resources, Louisiana State University, Baton Rouge, LA 70803. (C) 1990 American Institute of Biological Sciences.

\section{Management options can be effective at mitigating impacts of proposed alterations}

spatial effects of proposed human activities, the ability to separate these effects from natural changes, and the ability to appropriately modify the short-term incentive structures that guide local decision-making to better reflect these impacts (Costanza 1987a). Adequately predicting ecosystem impacts requires sophisticated computer simulation models that represent a synthesis of the best available understanding of the way these complex coastal ecosystems function.

The more general objectives of landscape modeling are to predict changes in land cover patterns across large geographic regions (tens to hundreds of kilometers) over long time scales (tens to hundreds of years) as a result of various site-specific management alternatives and natural changes. Development of this capability is needed for regional ecosystem management and also for modeling regional and global ecosystem response to regional and global climate change, sea level rise resulting from atmospheric $\mathrm{CO}_{2}$ enrichment, acid precipitation, toxic waste dumping, and a host of other potential impacts.

Two recent developments make this type of modeling feasible. First, the ready accessibility of extensive spatial and temporal databases from such sources as remote sensing and historical aerial photography make it possible to measure the behavior of real landscapes over large spatial and long temporal scales. Second, advances in computer power and convenience make it possible to build and run predictive landscape models at the necessary levels of spatial and temporal resolution.

\section{Coastal marshes}

The Atchafalaya delta and adjacent Terrebonne Parish marshes represent one of the most rapidly changing landscapes in the world. Figure 1 shows the study area. Figure 2 shows the historical sequence of Mississippi River main distributaries that have deposited sediments to form the current Mississippi deltaic plain marshes. This delta switching cycle (on average lasting 1500 years) sets the historical context of this landscape. At present, the river is in the process of changing from the current channel to the much shorter Atchafalaya River.

The US Army Corps of Engineers maintains a control structure at Old River (see Figure 1) to control the percentage of Mississippi River flow going down the Atchafalaya. For the last 40 years, this percentage has been set at approximately $30 \%$. Sediment borne by the Atchafalaya River first filled in open water areas in the upper Atchafalaya basin, and more recently it has begun to build a delta in Atchafalaya Bay (Roberts et al. 1980, Van Heerden and Roberts 1980a,b). Atchafalaya-borne sediments are dispersed 
to Fourleague Bay (Figure 3) and are contributing to marsh building in the eastern part of the study area as well (Baumann and Adams 1981, Baumann et al. 1984). During the next few decades, new delta is projected to form at the mouth of the river, and plant community succession will occur on the recently formed delta and in the existing marshes.

In contrast, the leveeing of the Mississippi and Atchafalaya rivers, along with the damming of distributaries, has virtually eliminated riverine sediment input to most Louisiana coastal marshes. This change has broken the deltaic cycle and greatly accelerated land loss. The overall Louisiana coastal zone has been projected to lose a net of approximately $100 \mathrm{~km}^{2} /$ yr due to sediment starvation and salt water intrusion (Gagliano et al. 1981). Only in the area of the Atchafalaya delta is sediment-laden water flowing into wetland areas and land gain occurring (Roberts et al. 1980, Van Heerden and Roberts 1980a,b).

Primary human activities that potentially contribute to wetland loss are flood control, canals, spoil banks, land reclamation, fluids withdrawal, and highway construction. There is evidence that canals and levees are an important factor in wetland loss in coastal Louisiana, but there is much disagreement about the magnitude of the indirect loss caused by them (Cleveland et al. 1981, Craig et al. 1979, Deegan et al. 1984, Leibowitz 1989, Scaife et al. 1983). Natural channels are generally not deep enough for the needs of oil recovery, navigation, pipelines, and drainage, so a vast network of canals has been built. In the Deltaic Plain of Louisiana, canals and their associated spoil banks of dredged material currently comprise $8 \%$ of the total marsh area compared to $2 \%$ in 1955 . The construction of canals leads to direct loss of marsh by dredging and spoil deposition and indirect loss by changing hydrology, sedimentation, and productivity. Canals are thought to lead to more rapid salinity intrusion, causing the death of freshwater vegetation. Canal spoil banks also limit water exchange with wetlands, thereby decreasing deposition of suspended sediments.

Proposed human activities can have a dramatic impact on the distribution

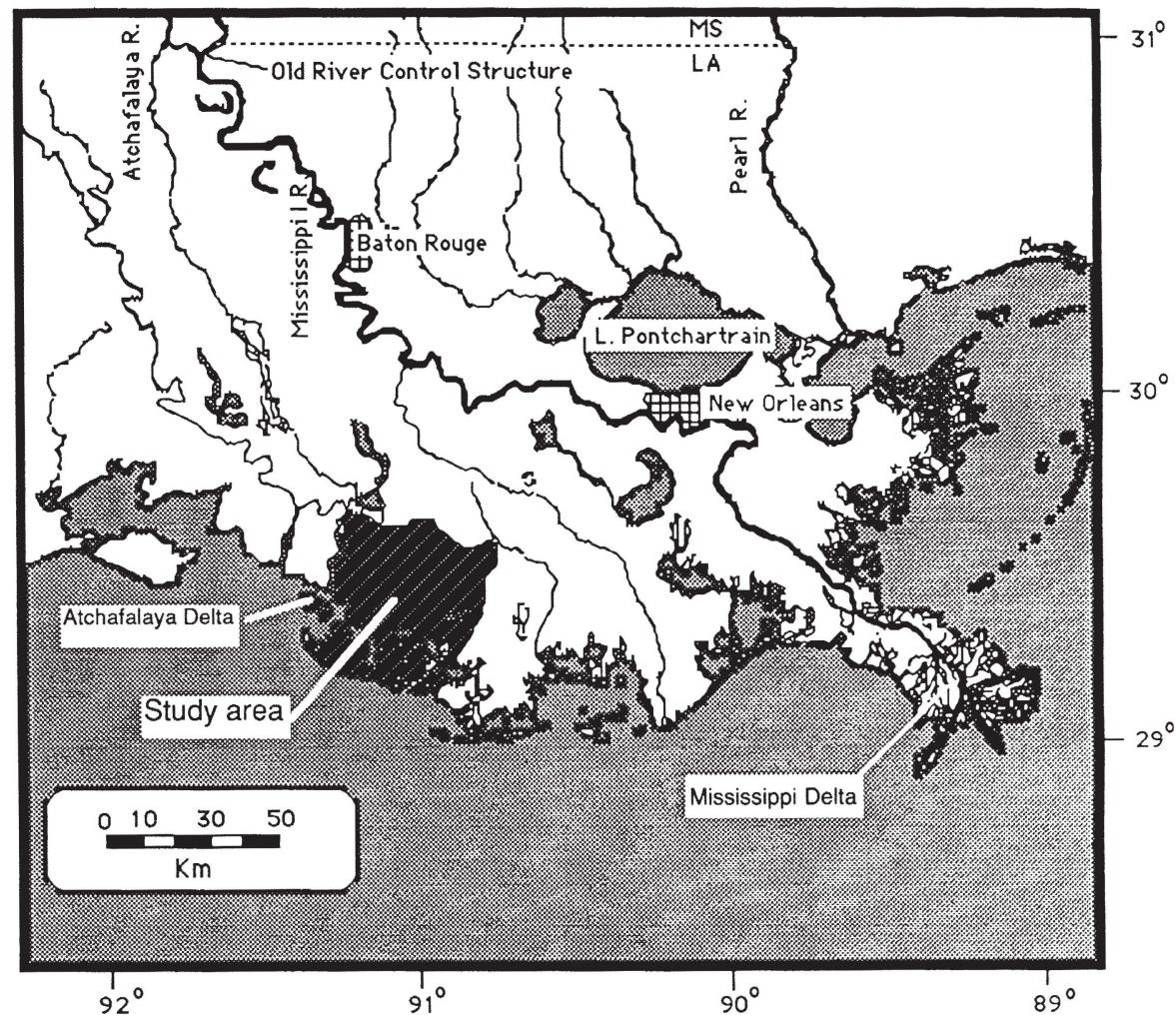

Figure 1. Map of southern Louisiana showing the Atchafalaya/Terrebonne study area.
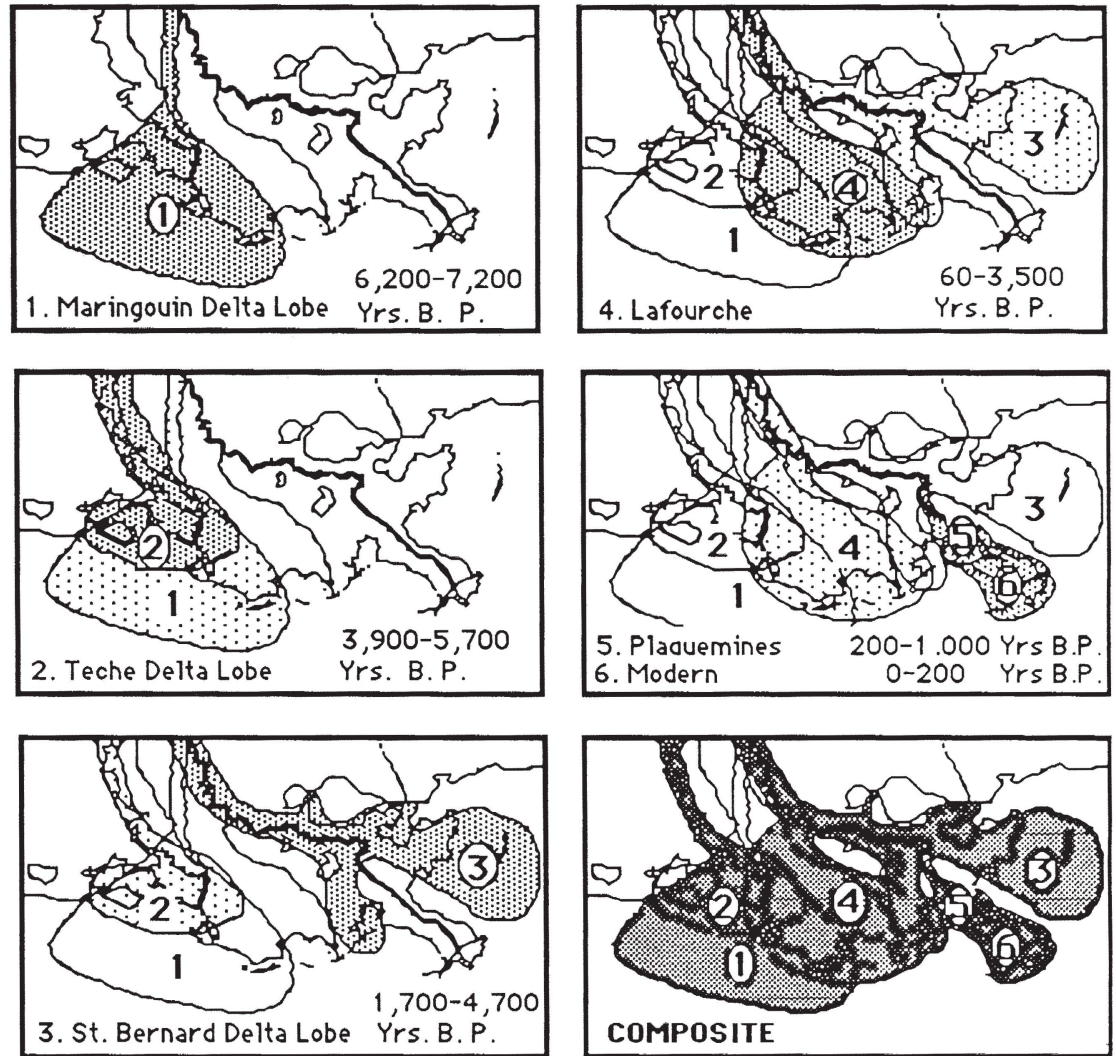

Figure 2. Historical sequence of major Mississippi River distributary changes. (After Baumann and Adams 1981.) 
of water and sediments from the Atchafalaya River, and consequently on the development of the Atchafalaya landscape. For example, the Corps of Engineers is considering extending a levee along the east bank of the Atchafalaya that would restrict water and sediment flow into the Terrebonne marshes (Figure 3). This situation represents a unique opportunity to study landscape dynamics. The Atchafalaya landscape is changing rapidly enough to provide time-series observations that can be used to test basic hypotheses about how coastal landscapes develop. In addition to short-term observations, there is a uniquely long and detailed history of field and remotely sensed data available on the study area (Bahr et al. 1983, Costanza et al. 1983).

Solutions to the land loss problem in Louisiana all have far-reaching implications. Outside forces (such as rates of sea level rise) also influence the effectiveness of any proposed solution. In the past, suggested solutions have been evaluated independently of each other and in an ad hoc manner. To more objectively evaluate the many interdependent implications of the various natural changes, management strategies, and specific projects that have been suggested to remedy the coastal erosion problem, an integrated spatial simulation modeling approach was developed (Costanza et al. 1988, Sklar et al. 1985, in press). Using this approach, we first demonstrated the ability to simulate the past behavior of the system, and then we projected future conditions as a function of various management alternatives and natural changes, both individually and in various combinations. Our approach simulates both the dynamic and spatial behavior of the system, and it keeps track of several of the important landscape level variables in the system, such as ecosystem type, water level and flow, sediment levels and sedimentation, subsidence, salinity, primary production, nutrient levels, and elevation.

\section{Process-based dynamic spatial ecosystem simulation models}

Ecosystem models can be differentiated from population models in that the former include biotic and abiotic components whereas the latter in-
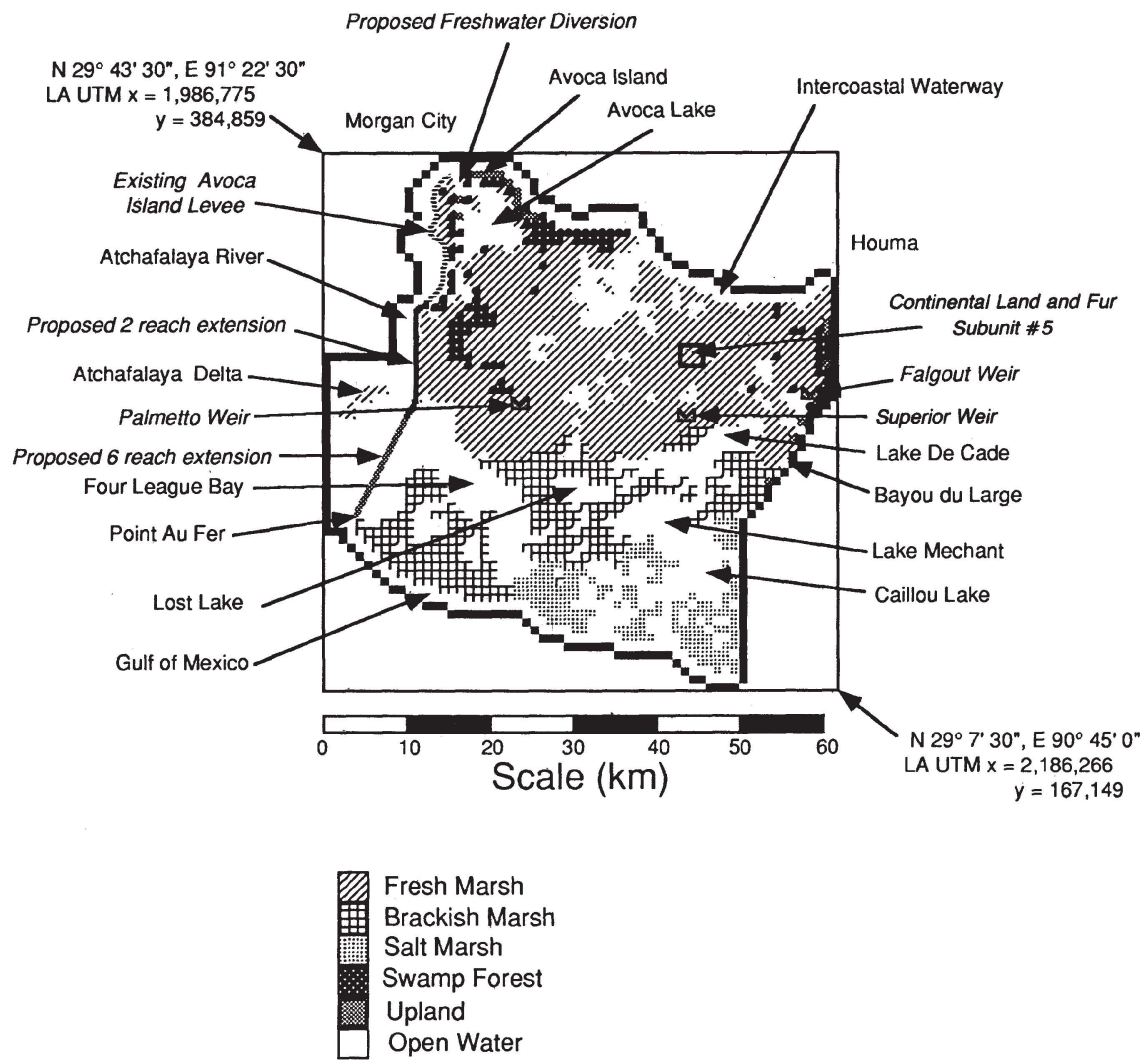

Figure 3. Atchafalaya/Terrebonne study area showing major geographic features, ecosystem types in 1983, and the location of the management options analyzed.

clude only populations of organisms. Ecosystem models tend to be more complex and realistic, and population models tend to be more simple and general. The majority of ecosystem models in the literature are designed to predict dynamic behavior while treating the system as spatially homogeneous (Costanza and Sklar 1985). Many existing ecosystem models are process based, in the sense of attempting to mimic (at least in an aggregated way) the underlying physical and ecological processes in the system, as opposed to statistical or probabilistic models, which are based directly on observed correlations in the data, generally without specifying mechanisms.

One way to extend the processbased approach to model spatial dynamics is to arrange a spatial array of point ecosystem models and connect them with fluxes of, for example, water and nutrients, employing rules to govern successional, evolutionary, or other changes in the structure of the system. This approach is some- what analogous to that employed in general atmospheric circulation models used in long-term climate modeling (Potter et al. 1979, Schlesinger and Zhao 1989, Washington and Williamson 1977, Williams et al. 1974), but it also incorporates elements of cellular automata and expert systems modeling incorporated in the successional rules.

Richard Levins (1966) first described the fundamental trade-offs in modeling between realism, precision, and generality. No single model can maximize all three goals, and the choice of which objectives to pursue depends on the fundamental purposes of the modeling study. Our approach favors higher realism and precision (the ability to and accurately realistically depict specific processes and ecosystems) at the expense of generality (direct and easy applicability to a broad range of systems). It is a relatively expensive and time-consuming approach to modeling that requires much site-specific data and a significant amount of effort to calibrate the 
model to local conditions. But the payoffs are significant in light of the cally a specific system. This approach was essential to achieve the analytical and management goals of our study.

The spatial process-based approach had been attempted in only a few previous cases for ecosystem modeling (Botkin et al. 1972, Costanza and Sklar 1985, Phipps 1979). In general, past applications were relatively successful, and their rarity is probably due to the size and complexity of the resultant models and the difficulty of assembling the necessary databases for calibrating and verifying the models. These limitations are decreasing with the increasing availability of remote sensing data and supercomputers, and we expect the relative expense of the spatial process-based approach to continue to decrease in the future.

\section{The CELSS model}

We developed a process-based spatial simulation model for the Atchafalaya/ Terrebonne marsh/estuarine complex in south Louisiana (Figure 3) called the coastal ecological landscape spamodel's ability to simulate realisti-

tial simulation (CELSS) model (Costanza et al. 1988, Sklar et al. 1989). The model consists of 2479 interconnected square cells, each representing 1 square kilometer. Each cell contains a dynamic ecosystem simulation model (Figure 4), and each cell is connected to its four nearest neighbors by the exchange of water and suspended materials (salts, nitrogen, and suspended organic and inorganic sediments). The buildup of land or the development of open water in a cell depends on the balance between net inputs of sediments and local organic peat deposition on the one hand and outputs due to erosion and subsidence on the other hand. The balance of sediment inputs and outputs is critical for predicting how marsh succession and productivity is affected by natural and human activities.

Inputs are specified in the form of time series during the simulation period. Weekly values of Atchafalaya and Mississippi river discharges, Gulf of Mexico salinity, river sediments and nutrients, rainfall, sea level, runoff, temperature, and winds are supplied to the simulation with each iteration. The location, time of con-

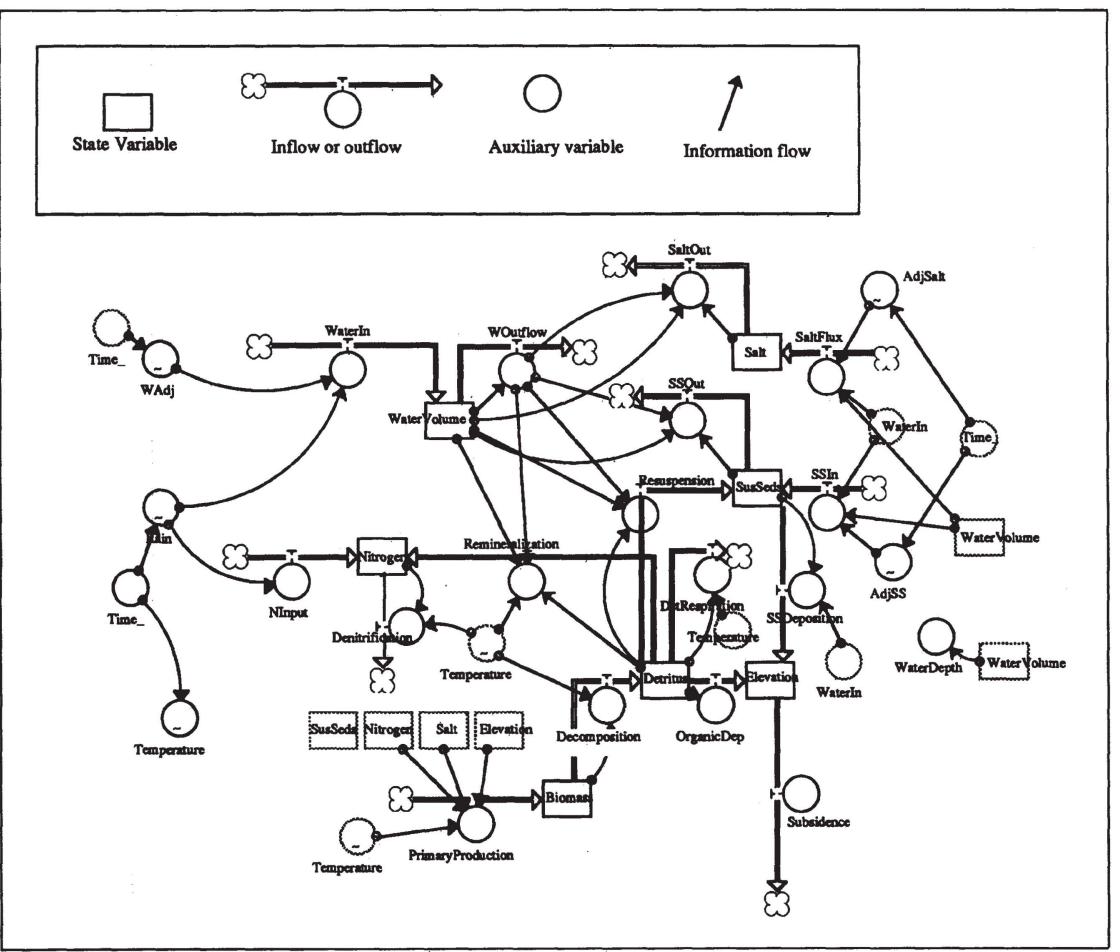

Figure 4. Diagram of a typical unit cell model in the CELSS landscape model in the STELLA modeling language (Costanza 1987b). All ecosystem types used a unit model with the same general structure, but with unique parameter settings.

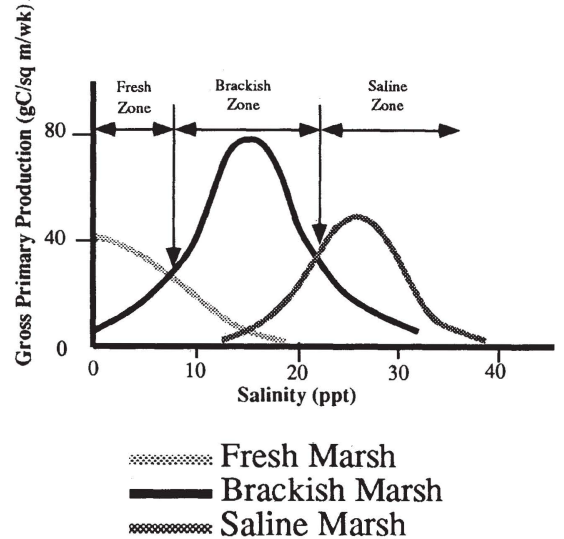

Figure 5. General relationship between gross primary production and salinity for three habitat types in the CELSS model. Data used to calibrate these relationships were taken from Conner and Day (1987).

struction, and characteristics of the major waterways, canals, and levees are also supplied as inputs to the simulation.

The change in water level in each cell is determined in the model by water exchanges in both directions across all four boundaries plus surplus rainfall (precipitation minus evapotranspiration). The hydrologic component of the model is, in essence, a two-dimensional, finitedifference, mass-balance model. Although this mass-balance approach does not accurately simulate shortterm hydrodynamics (because it leaves out momentum transfers, vertical dynamics, and Coriolis forces), it does approximate the major longerterm effects in our flat, shallow, and well-mixed study area.

It was necessary to give up some hydrologic precision because we needed to do continuous simulations for 58 years, which would have been prohibitively expensive using a complete hydrodynamic model, even on the fastest supercomputer. In addition, our primary goal in this model was to simulate plant community succession and productivity, conditions that respond more strongly to longerterm water flow patterns than to short-term flooding. Our results for water flow were similar to those produced for a few selected points in time by a more elaborate two-dimensional hydrodynamic model of the same area.

In our model, water can exchange 
with adjacent cells via canals, natural bayous, and overland flow, or it may be prevented from exchanging with adjacent cells by the presence of levees. An overall water flow connectivity parameter $(\mathrm{K})$ is adjusted during the model run to reflect the presence and size of waterways or levees at the cell boundaries. Connectivity is a function of habitat type, drainage density, waterway orientation, and levee height. If a waterway is present at a cell boundary, a large $K$ value is used, increasing with the size of the waterway. If a levee is present, a $\mathrm{K}$ value of 0 is used until water level exceeds the height of the levee. The model's canal and levee network is updated each year during a simulation run (i.e., dredged canals and levees are added to the model's hydrologic structure at the beginning of the year they were built).

Water crossing from one cell to another carries both organic and inorganic sediments. This sediment is partitioned between being deposited, resuspended, lost due to subsidence, and carried to the next cell. The relative rates of each of these sediment exchanges in each location is a function of ecosystem type. Plants and nutrients within each cell also influence these exchanges and flows. Changes in other abiotic material concentrations (i.e., salts and nitrogen) are also a function of water flow between cells and concentration of materials in the cells, along with internal deposition and resuspension (Figure 4).

The primary production in a cell is related to flooding regimes, turbidity, temperature, and elevation, according to functions like the one illustrated in Figure 5, which shows the model's relationship between weekly gross primary productivity and salinity for three of the habitat types. Data to calibrate the productivity functions was taken from Conner and Day (1987). In this type of function, maximal output occurs at optimal levels of inputs, and output is reduced with increased deviation from the optimum. The response of primary production to different nitrogen concentrations was stimulated with a Michaelis-Menten type rate equation, in which production continues to increase with increasing nitrogen, but at a decreasing rate. Data to calibrate
Table 1. Analysis of variance table for selected individual parameters and interactions of parameters on total fit of the model with 1978 conditions.

\begin{tabular}{lrrr}
\hline Parameter & Mean square & F value & Pr $>$ F \\
\hline Individual parameters & & & \\
Water flow (fresh marsh) & 2.30404601 & 5.31 & 0.0266 \\
Sedimentation & 0.12118223 & 0.28 & 0.6002 \\
Primary production & 8.31807987 & 19.16 & 0.0001 \\
Organic matter & 6.31000576 & 14.54 & 0.0005 \\
Water flow parameters & 0.00848915 & 0.02 & 0.8895 \\
Turbulent resuspension & 1.59570305 & 3.68 & 0.0625 \\
Water flow (open water) & 0.04134081 & 0.10 & 0.7592 \\
Subsidence & 3.59999056 & 8.29 & 0.0064 \\
& & & \\
Two-way interactions & & & \\
Water flow (fresh marsh) and sedimentation & 1.05885098 & 2.44 & 0.1264 \\
Water flow (fresh marsh) and primary production & 0.71286012 & 1.64 & 0.2076 \\
Water flow (fresh marsh) and organic matter & 0.19934273 & 0.46 & 0.5020 \\
Water flow (fresh marsh) and turbulent resuspension & 0.24456926 & 0.56 & 0.4574 \\
Water flow (fresh marsh) and subsidence & 0.51497506 & 1.19 & 0.2827 \\
Sedimentation and primary production & 2.00028590 & 4.61 & 0.0381 \\
Sedimentation and organic matter & 1.66397862 & 3.83 & 0.0574 \\
Sedimentation and turbulent resuspension & 2.91185842 & 6.71 & 0.0134 \\
Sedimentation and subsidence & 0.34385175 & 0.79 & 0.3789 \\
Primary production and organic matter & 4.65211481 & 10.72 & 0.0022 \\
Primary production and turbulent resuspension & 5.94659088 & 13.70 & 0.0007 \\
Primary production and subsidence & 2.23346004 & 5.15 & 0.0289 \\
Organic matter and turbulent resuspension & 0.54097224 & 1.25 & 0.2711 \\
Turbulent resuspension and subsidence & 0.09995870 & 0.23 & 0.6340 \\
Water flow (open water) and subsidence & 0.00524133 & 0.01 & 0.9131 \\
Three-way interactions & & & \\
Sedimentation and primary production and & 5.05771666 & 11.65 & 0.0015 \\
$\quad$ turbulent resuspension & & & \\
Error (degrees of freedom = 39) & 0.43402680 & & \\
\hline & & & \\
\hline
\end{tabular}

this function were taken from Hopkinson (1978).

Ecosystem succession occurs in the model (after a time lag) when the physical conditions in a cell become appropriate to a different ecosystem type. The program monitors the state variables in each cell and checks the physical environment (e.g., salinity, elevation, and water level). If the values of the state variables change to the extent that the environment in the cells is outside the range for its currently designated ecosystem type, then the cell's ecosystem type and all the associated parameter settings are switched to a new, better-adapted set. For example, if salinity in a cell that is fresh marsh rises beyond a certain threshold value and remains at this high level long enough, then the model converts the cell to brackish marsh and changes all the associated parameters.

The square cells have exchanges across their four sides. We did not use a hexagonal or triangular grid or a square one that allowed exchanges across the diagonals mainly because we wanted the simplest arrangement that would work reasonably well for our purposes and was easy to program. We used a simple Euler numerical integration technique with a variable time step. The maximal time step is one week. The model checks the rates of change of each variable, and if any of these is above a predetermined maximum it reduces the time step in increments until the rates of change are below the threshold, down to a minimum of one day.

The model was written in standard FORTRAN (3021 lines of code), and was run on a variety of computers, including a VAX 11/780, IBM 3034, and CRAY X/MP. A typical 22-year run at a weekly time step (1144 total time steps) for all 2479 cells with eight state variables each $(19,832$ total simultaneous difference equations) takes approximately 24 hours of CPU time on the VAX, 2 hours on the IBM, and 15 minutes on the CRAY. Most of the full-scale runs of the model were done on the CRAY, with the other computers used mainly in the early model development stages. 
Apple Macintoshs were used extensively for unit model design and debugging using STELLA (Costanza 1987b), for telecommunicating with the CRAY, and for mapping, analysis, and animation of results.

Input data. Primary input data for the model were: detailed, digitized ecosystem type maps prepared by the US Fish and Wildlife Service for 1956, 1978, and 1983; the history of canal and levee construction in the area, obtained from analysis of state permit records for the 1956-1978 period; a weekly record of climate variables, including rainfall, temperature, wind, river flow, and sediment and nutrient concentrations; and water level and salinity in the Gulf of Mexico. In addition, field measurements of productivity, biomass, and nutrient uptake were available for setting parameters for the productivity component of the model.

The model was initialized using the 1956 ecosystem type map. Because no direct measurements for the initial values for the model's other state variables in each cell were available, they were set at the middle of the range for the corresponding ecosystem type.

Calibration based on ecosystem type maps. Our first objective was to replicate the behavior of the system during the period from 1956 to 1978 and quantify the degree of fit between various alternative models and the data. The CELSS model was calibrated by starting it with the 1956 ecosystem type conditions and associated values for the other variables and simulating the evolution of the area during the intervening 22 years to 1978 with a maximum of weekly time steps. A measured ecosystem type map was available for 1978 for comparison with the model's predictions. The simulated and real maps were then compared for degree of fit. The model's parameters were iteratively adjusted within predetermined ranges of uncertainty to maximize the fit. The model was then continued to 1983 (for which a third map was available), and the fit was again calculated to estimate the model's predictive accuracy.

The CELSS model contains more than 130 parameters. In calibrating the model, we first choose initial val- ues and ranges of uncertainty for these parameters, based on available data and literature values. We then ran calibration runs of the model from 1956 to 1978 and compared the goodness of fit of the model's ecosystem type predictions with the 1978 data using visual inspection and the procedures described below. We also looked at the other variables in the model to make sure they were approximately replicating what we knew to have happened in the system.
But we concentrated on the ecosystem type predictions because ecosystem type is the result (in the model as well as in the real world) of the integration of the behavior of the other variables. Ecosystem type is also the most easily and accurately observed variable in the real system at the landscape scale.

We performed a preliminary parameter optimization by manually adjusting parameters within the predetermined ranges of uncertainty to improve the ecosystem type fit. When

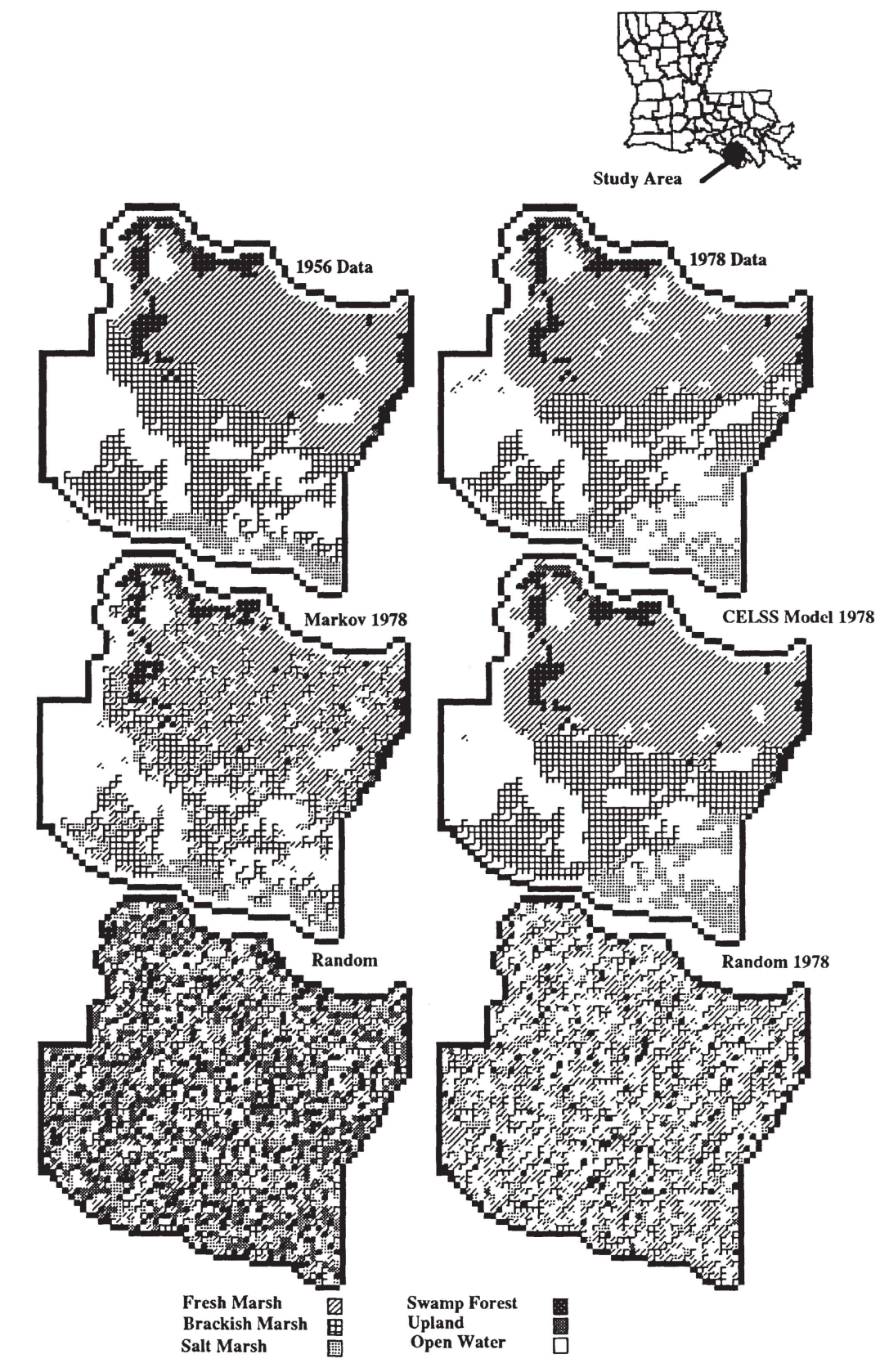

Figure 6. CELSS model and various alternative null model predictions for 1978 ecosystem type using the 1956 conditions as the starting point. 

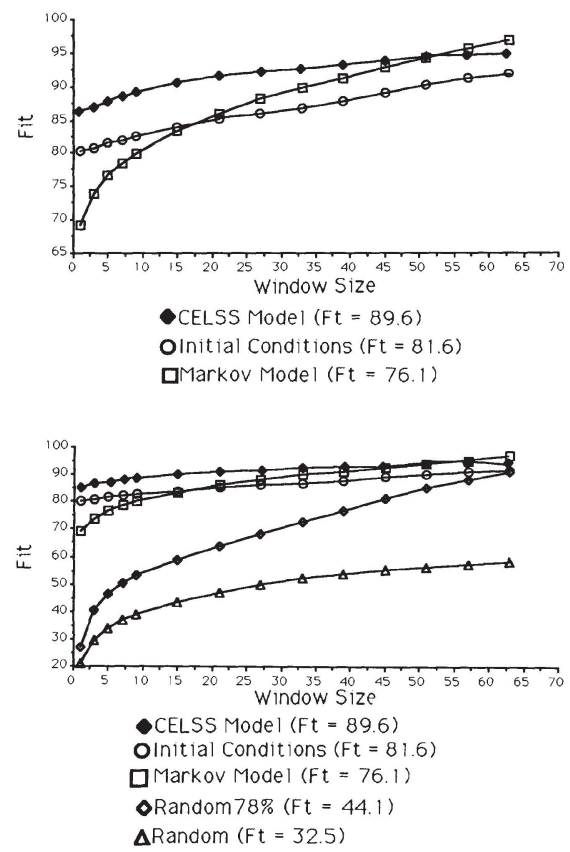

Figure 7. Example plots of fit versus window size for the various models in Figure 6 compared with the 1978 data. Upper graph shows the CELSS model, the Marov model, and the initial (1956) conditions on an expanded $y$-axis.

this procedure began to yield negligible improvements, we began a more formal parameter optimization procedure.

Because the model is nonlinear and has many discontinuities (due in part to the ecosystem succession algorithm), it is not amenable to traditional linear parameter optimization procedures, such as linear regression. We therefore used a procedure that is applicable to any model structure. This procedure treats the model as if it were an experiment (with the parameters as the controllable factors in the experiment) and uses traditional analysis-of-variance procedures to analyze the response of the model's fit to various combinations of changes in the parameters (factors). This method required a large number of simulation runs (one for each combination of parameter changes chosen) and was only possible for a model of this size because the speed of the supercomputer made generating the requisite number of runs feasible. A byproduct of this approach is a fairly elaborate sensitivity analysis of the model's response to changes in the parameters, which gave us significant insight into the model's behavior.

Table 1 shows the results of an analysis of the variance in fit due to the manipulated parameters and combinations of parameters. These results indicate that, although the physical and hydrologic parameters (such as water flow and subsidence) are important, the biological parameters (such as primary productivity), alone and in combination with the physical parameters, contribute significantly to controlling the fit of the model. It also appeared that our decision to use a process-based, whole-ecosystem approach was justified, because no single parameter explained most of the variation in fit and the higher order interactions between physical and biological parameters were significant.

We limited the parameters manipulated in this procedure to those of which we were most unsure, and, based on preliminary sensitivity analysis, those with the largest impact on the fit. Based on an analysis of the parameters, we could derive a set of changes in the parameter settings that would maximally improve the fit. We then implemented these changes and repeated the factorial experimental procedure. We iterated this process until significant improvements in fit were no longer being made. The base case CELSS model results reflect these optimized parameter settings.

Degree of fit of predicted ecosystem type with data. For relatively simple purposes, there are well-established statistical measures of goodness of fit. For example, a standard chi-square test can determine the fit between two categorical variables, but it ignores the spatial or other patterns of the variables. It could be used to determine if the total number of cells in each land use category were significantly different between two maps, but not whether there was a significant difference in the pattern of two maps that both had the same total number of cells in each land use category.

Landscape analysis requires quantifying the degree of matching of complex spatial and temporal patterns. Spatial pattern matching is not a straightforward statistical procedure. Even quantifying the degree to which nonspatial ecosystem modeling timeseries results match real patterns of ecosystem behavior is difficult and there is no agreed-on procedure (Gardner et al. 1982, Jørgensen 1982).

We used a multiple resolution approach to test the goodness-of-fit between the model and data. This approach allows a more complete analysis of the way the spatial patterns match (Costanza 1989, Turner et al. 1989). The algorithm gradually degrades the resolution with which the fit is measured by gradually increasing the size of a sampling window in which the fit is calculated. A plot of it versus window size (resolution) yields information on the way the patterns match. The total fit is estimated as a weighted average of the fit at all the window sizes, with the smaller window sizes given the most weight.

Figure 6 shows various model predictions for 1978 (including several null models) based on simulations using the 1956 conditions as the starting point. Figure 7 shows the variable resolution procedure applied to the spatial modeling results summarized in Figure 6. Fit versus window size is plotted for the 1978 data compared with the 1978 CELSS simulation model prediction (labeled "CELSS model") and with several alternative and null models.

The most simple-minded null model is a completely random distribution of habitats with all the categories being equally probable (labeled "random" in Figure 6). A slightly more reasonable null model is a random distribution but with the same

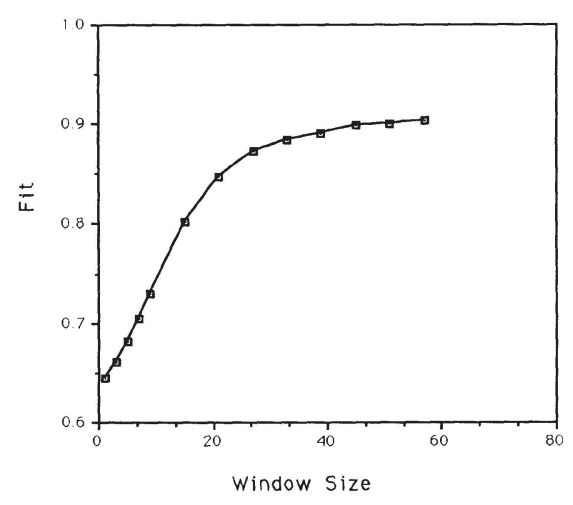

Figure 8. Comparison of CELSS model predictions for salinity with the WES twodimensional hydrodynamic model (Donnell and Letter 1989, Letter 1982) for low-flow conditions over a range of window sizes. 


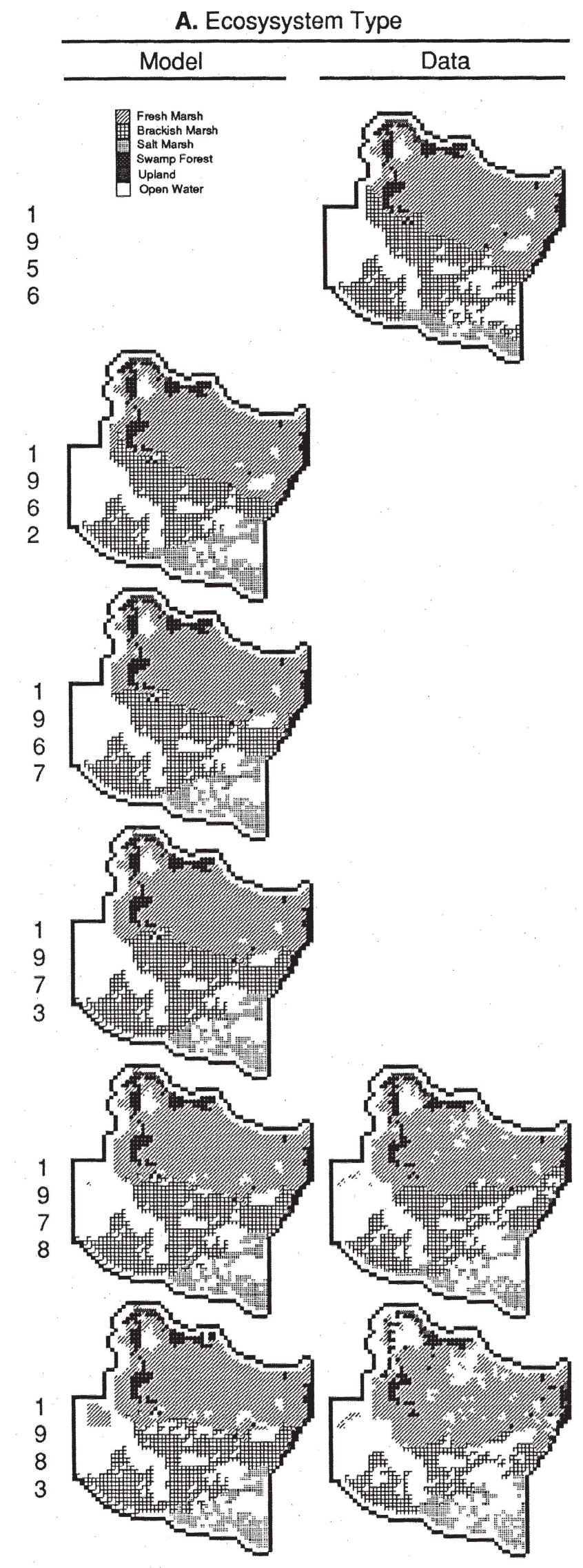

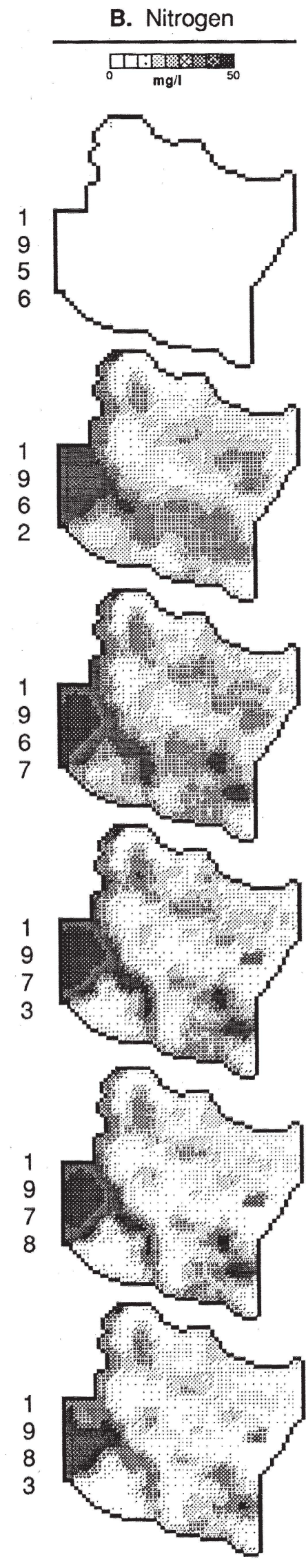

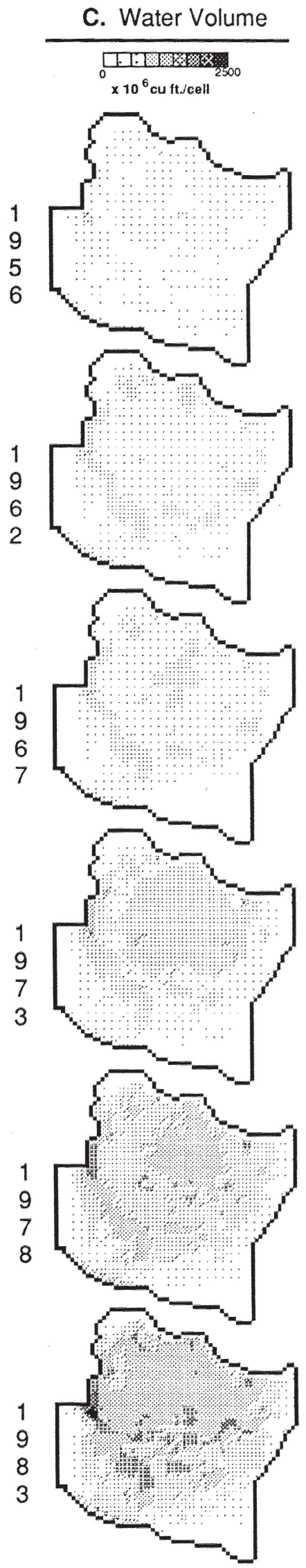

BioScience Vol. 40 No. 2 

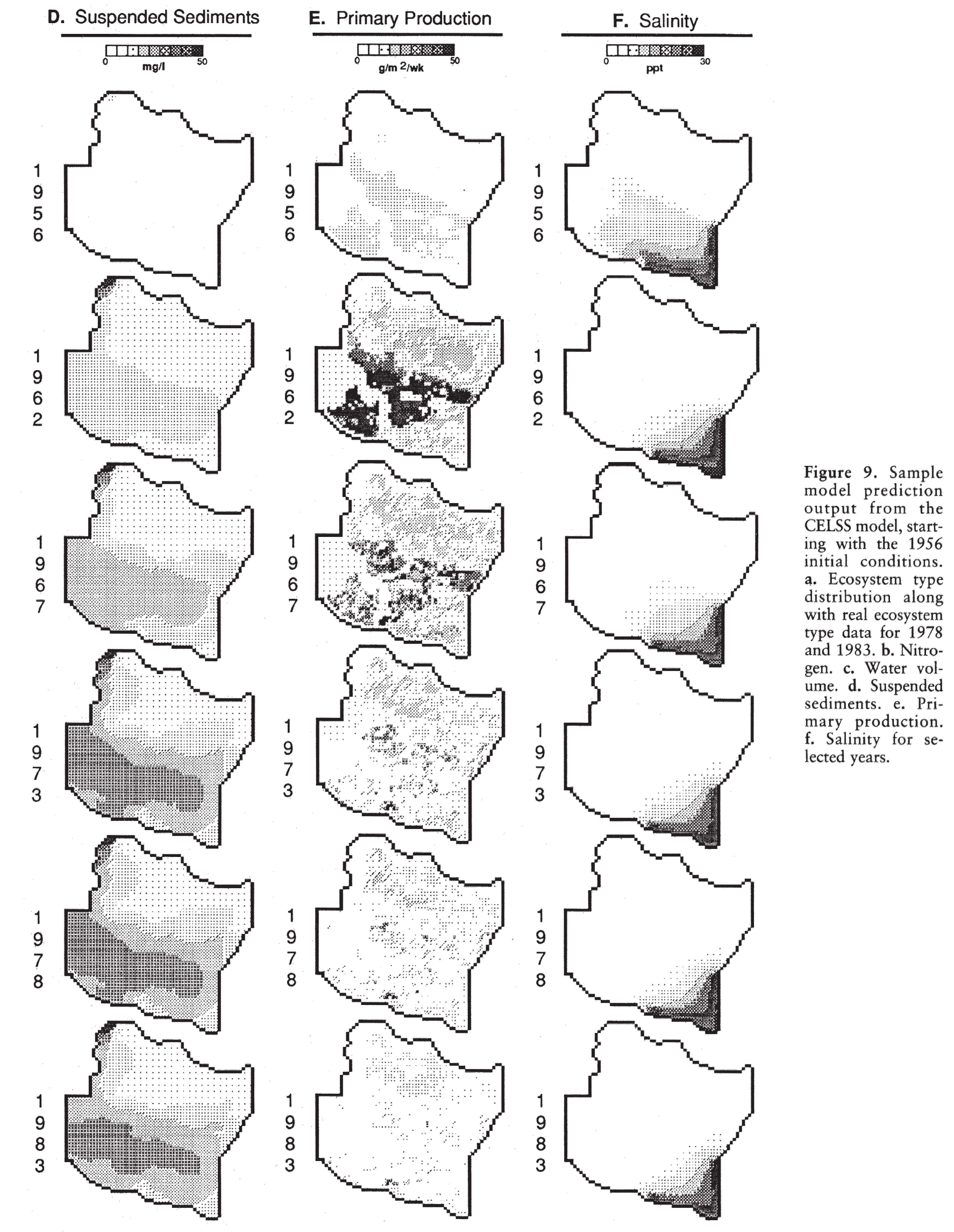

February 1990 
overall land cover probabilities (frequencies) as the 1978 data (labeled “random 1978"). A simple Markov chain model is a slightly more sophisticated null model that incorporates the statistical trend in habitat changes in the area in the form of transition probabilities (or frequencies) of each habitat type into each other type during the 1956-1978 interval. The fit for various window sizes for the Markov model is labeled "Markov model." Finally, the 1956 initial conditions represent a null model that predicts no change (labeled "initial conditions").

The CELSS simulation model performs better than any of the alternative or null models, but its performance can best be judged in relation to the null models. The simulation model fits the 1978 data better than "random" $\left\langle\mathrm{F}_{\mathrm{t}}=89.6 \%\right.$ versus $32.5 \%)$ and "random 1978" $\left(F_{t}=\right.$ $89.6 \%$ versus $50 \%$ ). The fit for "random 1978" approaches $100 \%$ as window size increases, indicating that the overall percentages of habitat types are the same, but the pattern is not well matched.

If only the fit at window size 1 is considered, the 1956 initial conditions null model does not appear to be much worse than the CELSS model $(86 \%$ versus $81 \%)$. The initial conditions null model appears to fit fairly well because only approximately $20 \%$ of the cells actually changed type between 1956 and 1978. But the pattern of fit is revealed by looking at the plots of fit versus window size in Figure 7. The CELSS model plot increases rapidly as window size increases indicating that the patterns of the model and data are similar. The initial conditions null model exhibits a flatter plot, indicating the patterns are not as similar. Total weighted fit $\left(\mathrm{F}_{\mathrm{t}}\right)$ reflects this added pattern matching $(89.6 \%$ versus $81.6 \%)$.

The Markov null model has a lower fit $(69 \%)$ at window size 1 than the initial conditions null model $(81 \%)$, but the fit increases more rapidly as window size increases. At the maximal window size, it fits better than the initial conditions model because the total number of cells of each type is closer to the 1978 data. Total weighted fit for the Markov model is less than the initial conditions model $(81.6 \%$ versus $76.1 \%)$ because, by randomly placing the transition cells, the detailed spatial pattern is disrupted even while the fit is increased at larger window sizes.

The CELSS model is the only alternative that also predicts changes in the underlying physical and ecological processes and that links these changes in a causal way to ecosystem type changes. Thus, even if it were only as good as the alternative models at predicting ecosystem type changes, the CELSS model would be preferred for management applications because it can address the underlying reasons for habitat changes and the relative impacts of human changes on these processes.

This is not to say that the CELSS model approach to spatial ecosystem modeling is in all aspects superior to other possible approaches. Like anything else, it has advantages and disadvantages. Its advantages are the ability to deal with a large, complex ecological system in a relatively realistic way. If the goal of the modeling effort is to make specific predictions about specific management alternatives in a specific region, then these advantages are crucial.

In achieving realism, however, this approach must sacrifice some generality. The model's parameters must be calibrated to historical conditions for each application of the model. Thus, while the CELSS modeling approach can be applied to any coastal area, its specific results in one area are not directly generalizable to other areas.

We compared the CELSS model simulations for some of the physical

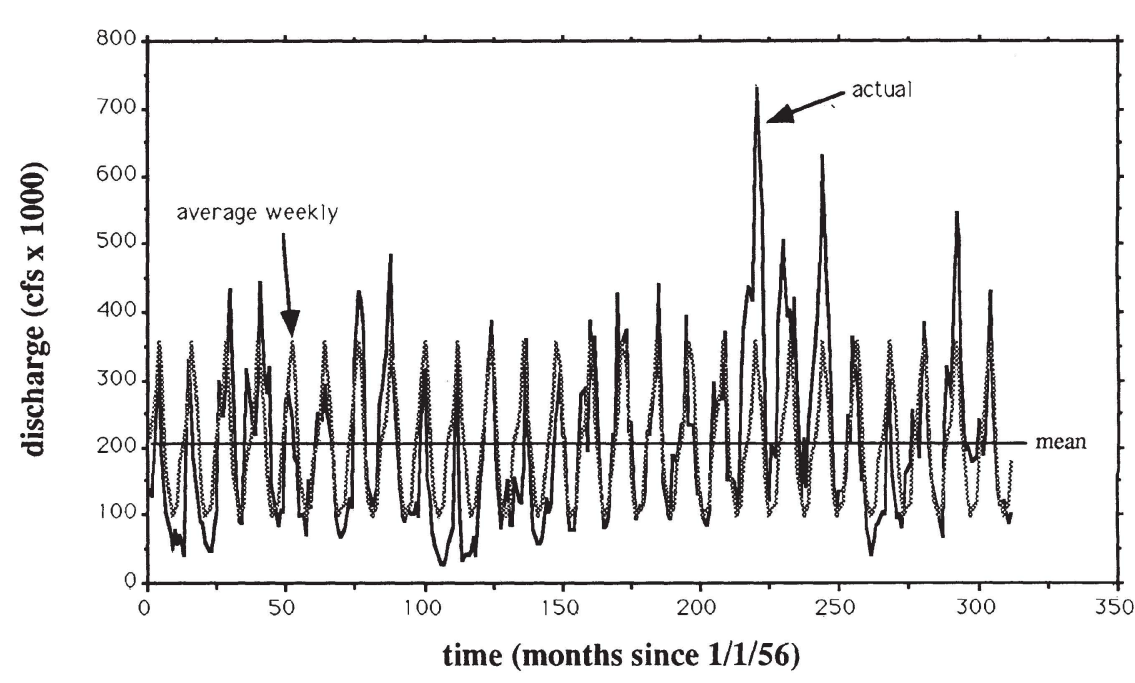

Figure 10. Atchafalaya River discharge data for 1956-1983 period. Also shown are the weekly average data and the mean for the period. variables with a more elaborate hydrodynamic model of the area constructed by the Corps of Engineers' Waterways Experiment Station (WES; Donnell and Letter in press, Letter 1982). The WES model deals with fewer variables (water, salt, and sediments) over much shorter time scales (maximum of one week continuous runs with time steps of minutes or seconds). It gives a more precise picture of short-term water, salt, and sediment levels and fluxes, whereas the CELSS model is more concerned with long-term ecosystem succession as driven by such factors as long-term water, salt, and sediment fluxes.

In general, the two models agree fairly well for their areas of overlap. Figure 8 shows the fit between the CELSS model and the WES model for salinity over several window sizes. The weighted average fit for this comparison was approximately $80 \%$.

No one model can provide a complete picture of a complex phenomenon such as Louisiana's coastal marshes. Like the blind men all feeling different parts of an elephant and coming to different conclusions about what it is, we must take the results of a suite of modeling and experimental studies and integrate them to provide a reasonable overall picture.

Base case output. The CELSS model can produce a huge amount of output. Some of the most useful pieces of output are contour maps for each of the eight state variables and for internal flows (i.e., sedimentation) and ex- 
changes between cells (i.e., water flow) for each week of the simulation. The results of the model are best comprehended by viewing animations of the model's time series mapped output for each of the variables. Here, we can only present a few example snapshots of the model's output and discuss some of the findings.

Figure 9 shows some sample output from the base-case run of the CELSS model, covering the period 19561983. Starting with the 1956 initial conditions, the model's predictions of average annual ecosystem distribution (the ecosystem that was present in the cell for the majority of the year), salinity, suspended sediments, water volume, nitrogen, and primary production for several years are shown, along with the real ecosystem type data for 1978 and 1983 for comparison with the model's output.

The CELSS model accurately reproduced the gradual intrusion of salt into the system from the southeastern part of the study area with the concurrent freshening in the southwestern sector due to increased Atchafalaya River input (Figure 9f). It also shows a loss of elevation in the north and an increase in elevation in the south. Both of these trends are indicative of river water and sediments moving further south in recent times, as well as a lack of connectivity with the more northern fresh marsh areas due to levee construction. Predicted water volume (Figure 9c) and suspended sediments (Figure 9d) behaved in a similar way and are generally consistent with what is known about the historical behavior of these variables in the area.

\section{Scenario analysis}

Once the model was calibrated, we analyzed a series of future and historical scenarios. The scenarios can be divided into four categories: climate scenarios, which address the impacts of climate variations on the model's behavior; management scenarios, which address the impacts of various internal site-specific manipulations to the system; historical scenarios, which address what the system would have looked like if the environment had not been altered by human intervention or if climatic conditions had been different, and boundary scenar-

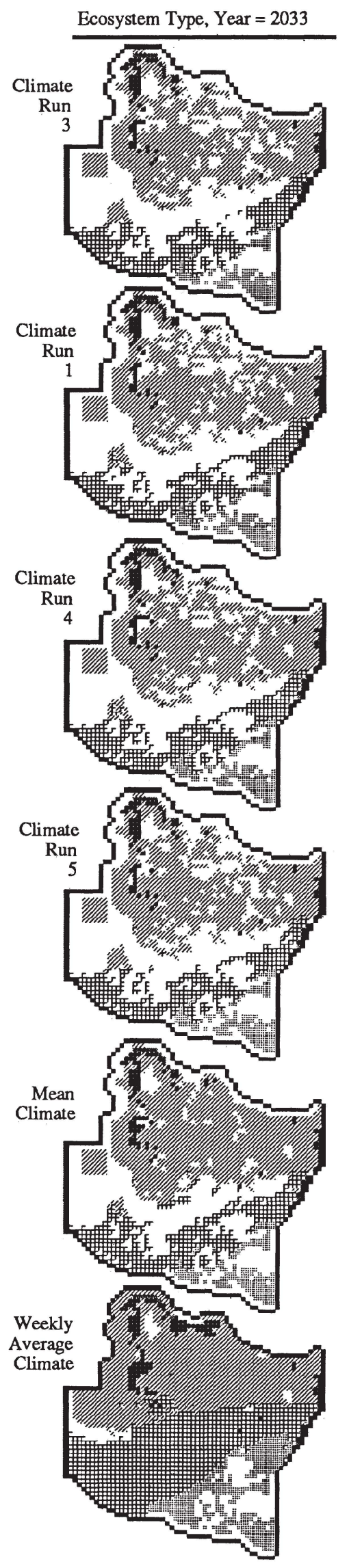

Differences with Climate run 3

Fresh Marsh Brackish Mars Salt Marsh Swamp Forest Upland Upland

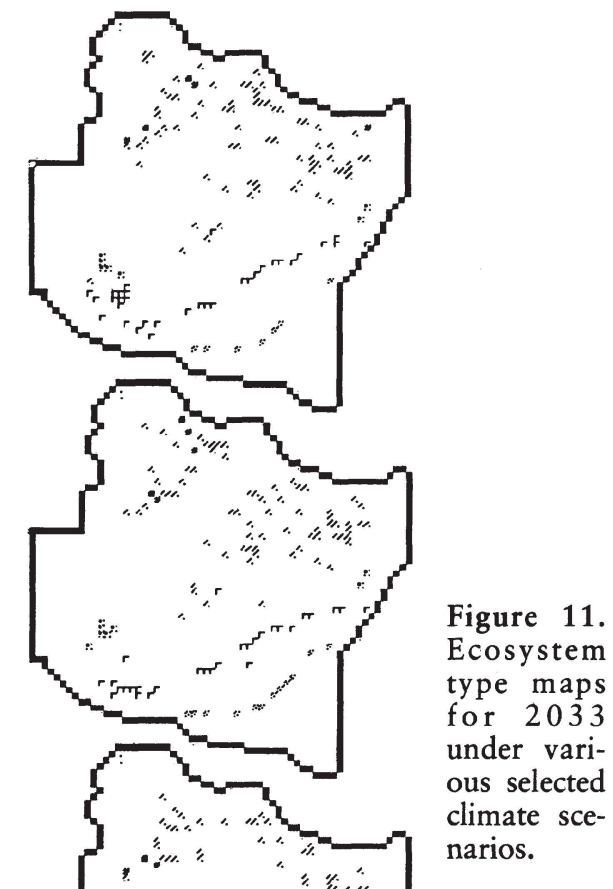

February 1990 
Table 2. Number of square kilometers of each ecosystem type for the three years for which data is available and for 2033 for various scenarios. Changes from the base case (in sqare kilometer) are indicated in parentheses.

\begin{tabular}{|c|c|c|c|c|c|c|c|}
\hline & Swamp & Fresh marsh & $\begin{array}{c}\text { Brackish } \\
\text { marsh }\end{array}$ & $\begin{array}{l}\text { Saline } \\
\text { marsh }\end{array}$ & Upland & Total land & Open water \\
\hline 1956 & 130 & 864 & 632 & 98 & 13 & 1737 & 742 \\
\hline 1978 & 113 & 766 & 554 & 150 & 18 & 1601 & 878 \\
\hline 1983 & 116 & 845 & 347 & 155 & 18 & 1481 & 998 \\
\hline \multicolumn{8}{|l|}{2033 Scenarios $^{*}$} \\
\hline \multicolumn{8}{|l|}{ Climate scenarios ${ }^{\dagger}$} \\
\hline Climate run 3 (climate base case) & 84 & 871 & 338 & 120 & 10 & 1423 & 1056 \\
\hline Climate run 1 & $79(-5)$ & $874 \quad(+3)$ & $337 \quad(-1)$ & $127 \quad(+7)$ & $(0)$ & $1427 \quad(+4)$ & 1052 \\
\hline Climate run 4 & $85(+1)$ & $900(+29)$ & $355(+17)$ & $130(+10)$ & $(0)$ & $1480(+57)$ & $(-57)$ \\
\hline Climate run 5 & $83(-1)$ & $891(+20)$ & $332(+6)$ & $126(+6)$ & $10(0)$ & $1442(+19)$ & $1037(-19)$ \\
\hline Mean climate & $94(+10)$ & $974(+103)$ & $402(+64)$ & $136(+16)$ & $11(+1)$ & $1617(+194)$ & $862(-194)$ \\
\hline Weekly average climate & $128(+44)$ & $961(+90)$ & $813(+475)$ & $300(+180)$ & $11(+1)$ & $2213(+790)$ & $266(-790)$ \\
\hline \multicolumn{8}{|l|}{ Management scenarios } \\
\hline No levee extension (base case) & 100 & 796 & 410 & 123 & 15 & 1444 & 1035 \\
\hline Two-reach levee extension & $98(-2)$ & $(+8)$ & $399(-11)$ & 123 & $(0)$ & 1439 & 1040 \\
\hline CLF marsh management & $102(+2)$ & $(+2)$ & $409 \quad(-1)$ & 123 & $15(0)$ & 1447 & 1032 \\
\hline Falgout Weir & $104(+4)$ & $(+3)$ & $(-7)$ & $(-1)$ & $16(+1)$ & 1444 & 1035 \\
\hline Full six-reach levee extension & $103(+3)$ & $(-6)$ & $362(-48)$ & $(-1)$ & $15(0)$ & $1392(-52)$ & $(+52)$ \\
\hline Fresh-water diversion (FWD) & $103(+3)$ & $(+7)$ & $404(-6)$ & 123 & $(0)$ & $1448 \quad(+4)$ & 1031 \\
\hline FWD and Palmetto Weir & $102(+2)$ & $(+6)$ & $(-3)$ & 123 & (0) & 1449 & 1030 \\
\hline FWD and Superior Weir & $104(+4)$ & $(+3)$ & $(-6)$ & 123 & $(0)$ & 1445 & 1034 \\
\hline FWD and Superior and Palmetto weirs & $104(+4)$ & $(-4)$ & $(-3)$ & 123 & (0) & 1441 & 1038 \\
\hline FWD and Superior and Falgout weirs & $104(+4)$ & $(+7)$ & $(-3)$ & $(-1)$ & $(0)$ & 1451 & 1028 \\
\hline \multicolumn{8}{|l|}{ Boundary scenarios $^{\ddagger}$} \\
\hline EPA low sea level rise & $104(+4)$ & $(+4)$ & $411(+1)$ & $(+1)$ & $(0)$ & $1454(+10)$ & $(-10)$ \\
\hline EPA high sea level rise & $89(-11)$ & $(-2)$ & $396(-14)$ & $(+8)$ & (0) & $1425(-19)$ & $1054(+19)$ \\
\hline \multicolumn{8}{|l|}{ Historical scenarios $\$$} \\
\hline No original Avoca Levee & 84 & 951 & 350 & 126 & 13 & 1524 & 955 \\
\hline No effects & 130 & 863 & 401 & 144 & 12 & 1550 & 929 \\
\hline
\end{tabular}

* The summary maps and this table indicate the dominant habitat type for each cell (i.e., the ecosystem type present in the cell for the largest amount of time during the year). Alternatively, we could have added the total number of cells of each ecosystem type for each week of the simulated year and divided the totals by 52 . Although this gives a somewhat more accurate picture of the habitat distribution, it is inconsistent with the totals from the maps.

tThe climate analysis scenarios used a slightly different set of parameters for the model than the other scenarios. See text for details.

‡EPA low scenario is a 50 -centimeter rise by 2100 . We used $0.46 \mathrm{~cm} / \mathrm{yr}$, which is double the historical rate of eustatic sea level rise in the study area of $0.23 \mathrm{~cm} / \mathrm{yr}$. Subsidence in the study area varies horizontally from 0.57 to $1.17 \mathrm{~cm} / \mathrm{yr}$, giving historical rates of apparent sea level rise (eustatic rise plus subsidence) of 0.8 to $1.4 \mathrm{~cm} / \mathrm{yr}$. EPA high scenario is a 200 -centimeter rise by 2100 (1.67 cm/yr eustatic or 2.24 to $2.84 \mathrm{~cm} / \mathrm{yr}$ apparent). Base case for comparison was no levee extension.

${ }^{\$}$ No comparisons with a base case are given for the historical scenarios because these runs started in 1956 rather than 1983.

ios, which address the impacts of natural and human-induced variations in the systems' boundary conditions (i.e., sea level rise).

Management and boundary scenarios were run by restarting the model with the real 1983 ecosystem type map (rather than the model's predicted $1983 \mathrm{map}$ ) to ensure maximal realism. Climate and historical scenarios were run starting with 1956 , so that the full impacts of climate and historical variations could be analyzed. After 1978, canal and levee construction for oil and gas exploration slowed significantly in the area compared with the 1956-1978 period. Therefore, all scenarios assumed that no additional canals or levees were constructed after 1978, except those specifically mentioned in the scenarios.

We present summary maps of the ecosystem type in the year 2033 for comparison of alternatives (Figures 11,13 , and 14). We also further summarize the results in Table 2, which lists for each alternative the total area of each ecosystem type in 2033, along with differences between each scenario and the base case.

Climate scenarios. Predicting future marsh succession required that we provide the model with predictions of future climate and boundary conditions. By climate we mean all the model's external forcing functions, including rainfall, Atchafalaya River flow, wind, and sea level.

For example, Figure 10 is a plot of Atchafalaya River discharge during the 1956-1983 period showing the weekly data used in calibrating the model. To project the base case climate into the future, we selected at random one-, two-, or three-year blocks from this record, modified them by randomly increasing or decreasing each point a maximum of $10 \%$, and added this block to the end of the projected time series. This exercise provided a series of future years that were statistically identical to the past record and included the seasonal timing of the historical signals, but allowed for some novel random variations. We produced several future climate runs with this algorithm and tested the model's response to each. Some examples are shown in Figure 11.

We were also interested in what 
part of the behavior of the system was due to random, aperiodic variations in climatic variables; what part was due to the annual periodic signal; and what part was due to the mean or average signal. We therefore analyzed two additional climate scenarios. These were the weekly average climate scenario, in which each week's value for each climate variable for the entire run from 1956 to 2033 was set at the average value for that week from the 1956 to 1983 data, and the mean-climate scenario, in which the long-term average for each variable was used for all weeks. For example, Figure 10 shows both the weekly average and mean signals for Atchafalaya River discharge.

Figures 11 and 12 show the projected ecosystem type maps for the year 2033 and a summary of the land/water balance in the system during the 1956-2033 period for the various climate scenarios. These figures clearly show the major effect of differing climate assumptions on the model. The base case runs show a moderate amount of difference due to the different random components in each run, but the general behavior was approximately the same. In all other future scenarios, we used the climate run labeled 3, because this case produced intermediate results.

The degree to which the other climate scenarios affected the results was surprising. The weekly average climate scenario produced a drastic reversal in land loss in the area. The mean climate scenario produced only a moderate decrease in land loss. This result indicates that the annual flood cycle and other annual periodicities in the climate are important to the land building process, but that random, aperiodic events (such as major storms and floods) tend to have a net erosional effect on marshland. A periodic but predictable climate seems to maximize marsh building. If global climate becomes less predictable in the future due to global warming, it may bode ill for the stability of coastal marshes.

Management alternatives. A base case run and several management alternatives were analyzed using the model. The results for 2033 for selected alternatives are summarized in Figure 13a and Table 2. The figure shows

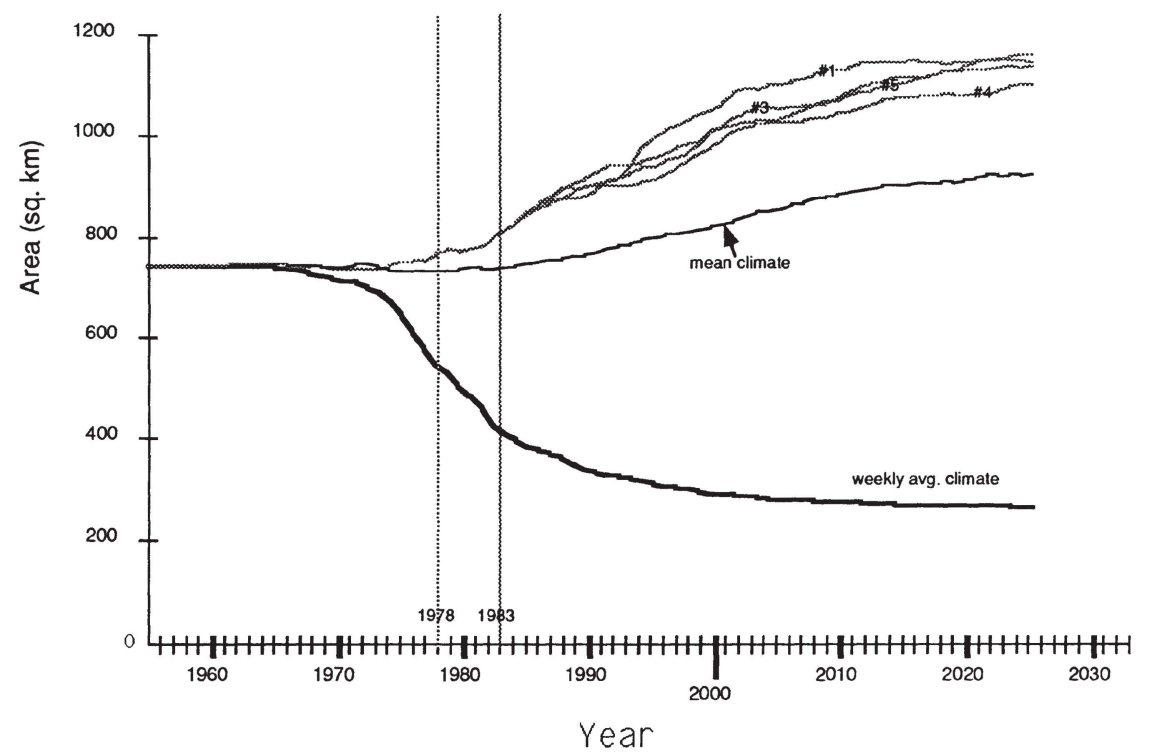

Figure 12. Summary time series of total open water area predictions under various climate scenarios.

both the ecosystem type map resulting from each alternative in 2033 and the cells that are different from those in the base case run, regardless of the direction of change. All the alternatives (see Figure 3) except the base case assume the two-reach Avoca Island levee extension (a 15-kilometer extension to the current levee system on the Atchafalaya River) has been built. The results for the other management options therefore indicate the amount of remaining (unmitigated) impact from the two-reach levee extension. All alternatives used climate run 3.

BASE CASE. The base case of the model assumed the canal network fixed as it was in 1978. As shown in Table 2, the base case run indicates a net land loss to open water of $37 \mathrm{~km}^{2}$ from 1983 to 2033. Most of this loss occurred in fresh $\left(-49 \mathrm{~km}^{2}\right)$ or saline marsh $\left(-32 \mathrm{~km}^{2}\right)$ that was either converted to open water or to brackish marsh $\left(+63 \mathrm{~km}^{2}\right)$ due to continued fresh water inputs via the Atchafalaya River.

The overall rate of land loss predicted by the model to occur after $1983\left(0.75 \mathrm{~km}^{2} / \mathrm{yr}\right)$ was much lower than the rates between 1956 and $1978\left(6.2 \mathrm{~km}^{2} / \mathrm{yr}\right)$ and between 1978 and $1983\left(24 \mathrm{~km}^{2} / \mathrm{yr}\right)$. There was therefore some concern that the model may be seriously underestimating the future rate of land loss.
To test the model's predictions, we performed a careful visual inspection of infrared aerial photographs taken in December 1988, which indicated that the rates of land loss have indeed slowed dramatically in the study area. Areas which appeared stressed in 1983 and which might have been expected to succeed to open water habitat have remained as marsh, as the model predicted. There were no apparent areas of significant marsh loss in the study area between 1983 and 1988 , as predicted by the base case run of the model. The 1988 photographs are currently being interpreted and digitized to allow a quantitative assessment of the model's predictions, but it is clear that the model provided a better prediction of the status of the area in 1988 than predictions based on simple extrapolation of past trends. This finding underscores the effectiveness of our spatial, process-based approach to landscape modeling.

TwO-REACH LEVEE EXTENSION. The model was then modified in structure to allow for the construction of the first two reaches of the proposed Avoca Island levee extension. All other model parameters were held constant and identical climate inputs were used. The predicted effects are the indirect effects of the construction and do not include the acreage directly affected by construction. 


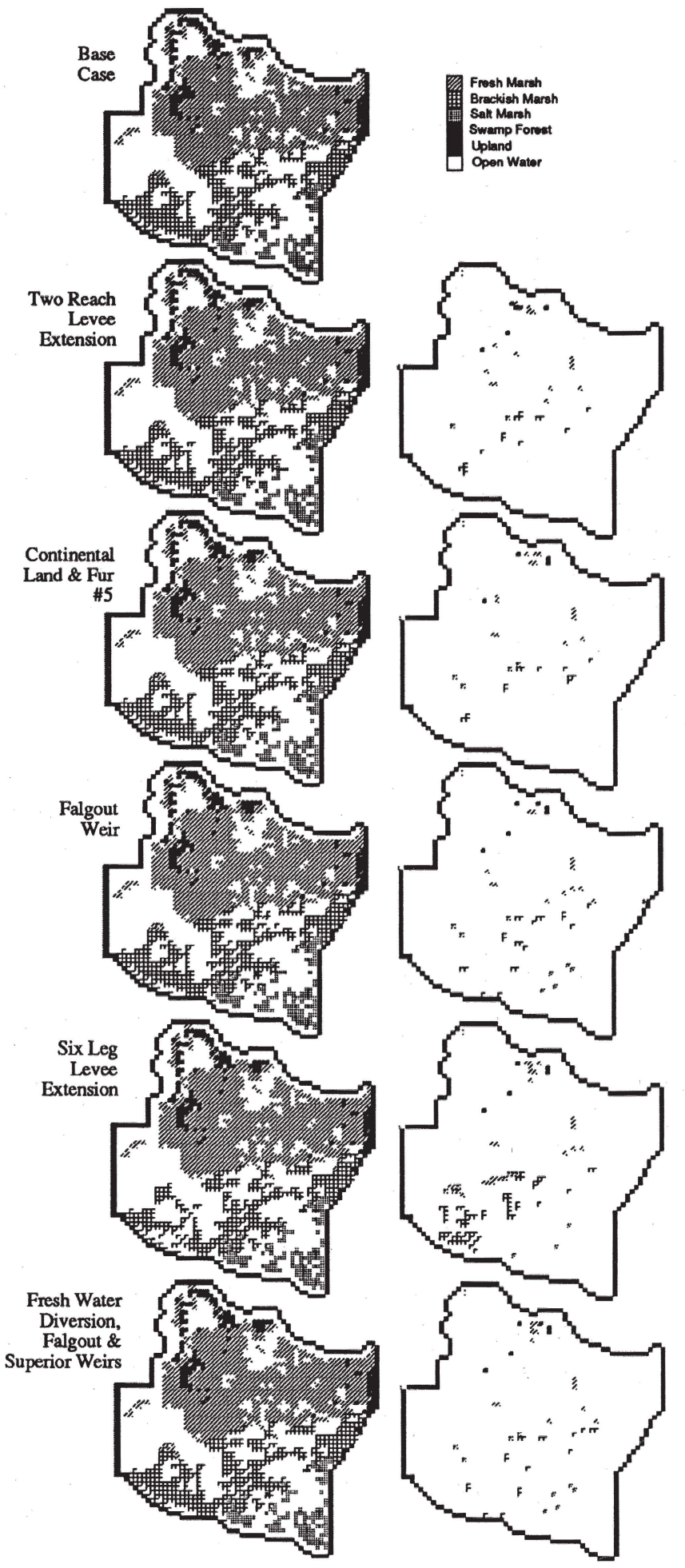

Figure 13. a. Ecosystem type maps for 2033 under various management scenarios. b. Ecosystem type maps for 2033 under various boundary and historical scenarios.

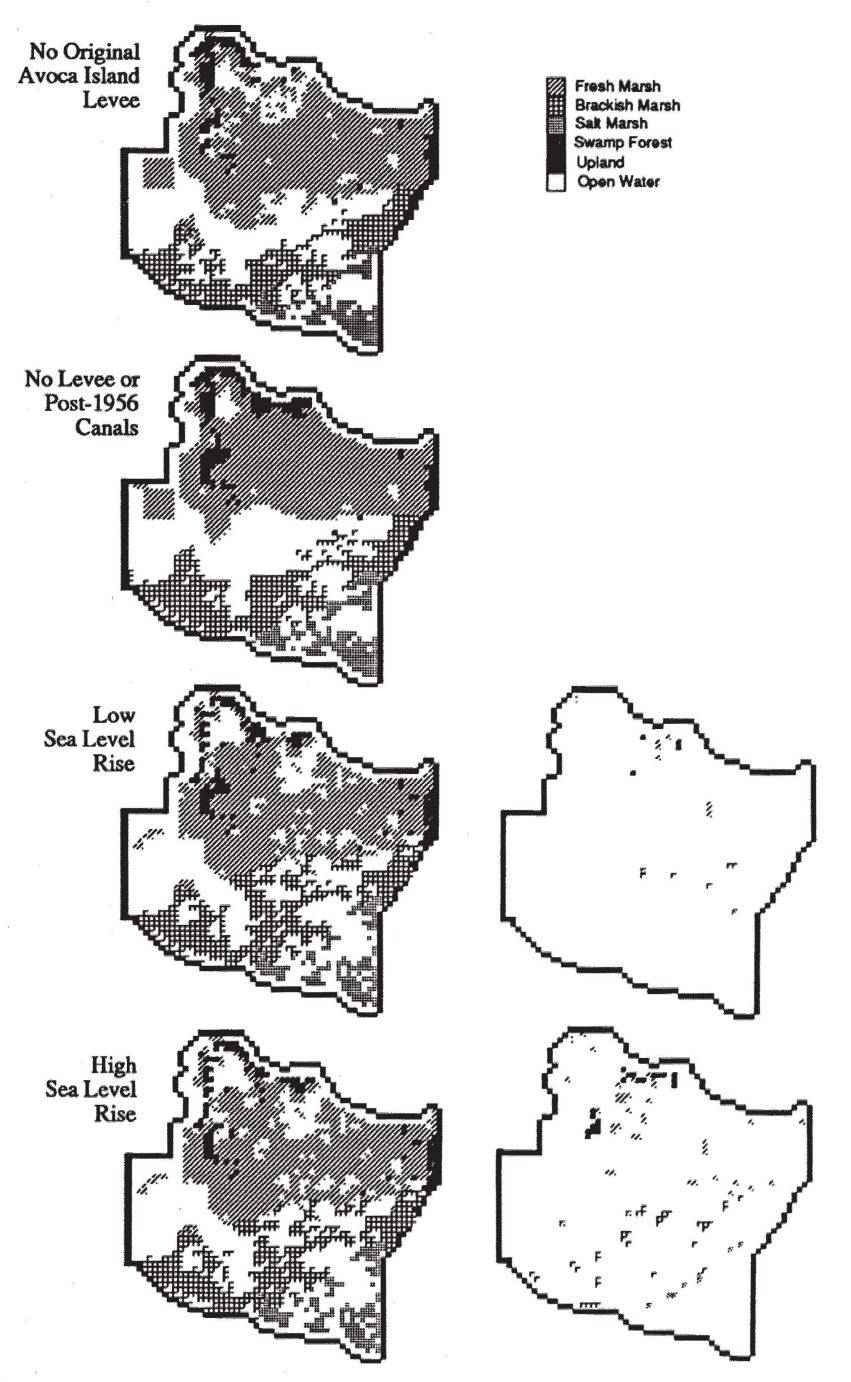

The result was a relatively modest net negative land loss $\left(-5 \mathrm{~km}^{2}\right)$ compared to the base case, mostly from the brackish marsh category. Most of the effects were at the fresh/brackish interface, due to the redirection of fresh water by the levee extension further south in the study area. All the other management alternatives assumed the two-reach levee extension was in place, so that their ability to mitigate its effects could be estimated.

CONTINENTAL LAND AND Fur MARSH MANAGEMENT PLAN. Implementation in the model of Soil Conservation Service Treatment Unit \#5 of the Continental Land and Fur proposed marsh management plan involved establishing levees and weirs 
to control water levels in an approximately 4-square-kilometer area (see Figure 3). The plan was installed in 1988 , three years after the proposed levee extension was implemented in the model. This alternative resulted in a slight net gain of land $\left(+3 \mathrm{~km}^{2}\right)$ relative to the base case. It caused modest gains in fresh marsh and swamp ( $+2 \mathrm{~km}^{2}$ each) balanced by smaller losses in brackish marsh $(-1$ $\mathrm{km}^{2}$ ) due to indirect effects on water flow patterns.

FALGOUT WEIR. Implementation of this alternative involved a run of the model with a weir at the entrance of the Falgout Canal, beginning in model year 1985 . This alternative resulted in zero net gain of land relative to the base case. It caused increases in fresh marsh (probably due to reduction of salt water intrusion) and swamp, but also caused losses in brackish marsh that canceled out these gains.

FULL SIX-REACH LEVEE EXTENSION. We also analyzed the full six-reach $(25 \mathrm{~km})$ levee extension that had been under consideration at one time (see Figure 3). This scenario involved introducing the levee extension beginning in 1983, with completion of the final reach in 1988. This alternative results in a relatively large net loss of land $\left(-52 \mathrm{~km}^{2}\right)$ relative to the base case. The majority of the loss was from the brackish marsh $\left(-48 \mathrm{~km}^{2}\right)$ and, to a lesser extent, from the fresh marsh $\left(-6 \mathrm{~km}^{2}\right)$. The full levee extension prevented sediment-laden water from reaching the brackish marshes bordering Four League Bay, where most of the loss occurs.

FRESH-WATER DIVERSION STRUCTURE. This run of the model included a fresh-water diversion structure located in the northwest corner of Avoca Lake (see Figure 3), installed in 1985. The fresh-water diversion structure would allow $2 \%$ of the Atchafalaya River flow to be diverted into the Terrebonne Marsh, up to a river flow of 370,000 cubic feet per second. At and above this flow, the diversion flow is turned off to prevent backwater flooding.

This alternative resulted in a net gain of land $\left(+4 \mathrm{~km}^{2}\right)$ relative to the base case. The filling of Avoca Lake with sediments, which would be expected to occur with a water diversion structure, did not take place in the model. The flow of water did not allow for significant sedimentation because the turbulence is too high near the division structure. The CELSS model does not, however, currently distinguish sediment grain sizes, and it may not adequately account for large-grain sediments that fall out quickly near a diversion site. If coarse-grained sediments make up a significant fraction of the total, the net land gain under this scenario may therefore be higher than the model predicts.

Palmetto Weir and FReshWATER DIVERSION. Implementation of this alternative involved a run of the model with a weir on Palmetto Bayou (see Figure 3). The weir was installed in model year 1985 and allowed flow one way to the south. The fresh-water diversion structure was installed as described above and run with the same limits on the river flow conditions.

This alternative resulted in a 5square-kilometer net land gain relative to the base case and only a one-cell land gain relative to the simulation with fresh-water diversion as the only mitigation. Because the weir is preventing the newly diverted water from flowing out Palmetto Bayou, redirected water has beneficial effects in the brackish marsh. It does, however, flood some of the fresh marsh just north of the weir.

SUPERIOR WEIR AND FRESH-WATER DIVERSION. Implementation of this alternative involved a run of the model with a weir on Superior Canal at the location of an existing plug (see Figure $3)$. The weir was installed in model year 1985 and allowed flow one way to the south. The fresh-water diversion structure was installed as described above and run with the same limits on the river flow conditions.

This alternative resulted in a 1square-kilometer net land gain relative to the base case. The swamp habitat in the north is prevented from succeeding to open water, and land loss occurs just to the north. The retardation of the diverted water, which is beneficial to the swamp, waterlogs the marsh in the south and causes land loss there.

FRESH-WATER DIVERSION STRUCTURE AND BOTH PALMETTO AND SUPERIOR WEIRS. This run included the fresh-water diversion structure and both the Palmetto Bayou Weir and the Superior Canal Weir, as described above. This model run illustrates the importance of cumulative impacts. In this scenario there is a net loss of land $\left(-3 \mathrm{~km}^{2}\right)$ relative to the base case. This net loss occurs even though the structures each produced a predicted net gain when used individually. The effects are not additive, however. The positive effects of the sediments in the fresh water are overcome by the negative effects of waterlogging when both weirs are used, but not when either one is used by itself. There is some optimal balance of waterdiversion rate and location and weir location that can best be determined by iterative simulations of a model of this type.

FRESH-WATER DIVERSION STRUCTURE AND bOTH FAlgout and SupeRIOR WEIRS. This scenario included the Falgout Canal Weir, the Palmetto Bayou Weir, and the fresh-water diversion structure. This alternative resulted in a net gain of land $\left(+7 \mathrm{~km}^{2}\right)$ relative to the base case. This net gain occurred mainly in the swamp and fresh marsh ecosystem types, due mainly to increased sediment flows to these areas as a result of the diversion. This combination of management alternatives yielded the largest positive net land gain of those we have investigated thus far.

Boundary scenarios. One important boundary scenario was analyzed-the effect of increasing rates of future sea level rise due to global warming. Projected rates of future sea level rise are in the range of 50 to $200 \mathrm{~cm}$ during the next 120 years (or 0.42 to 1.67 $\mathrm{cm} / \mathrm{yr}$; Titus 1988) Coastal Louisiana has historically experienced high rates of apparent sea level rise due to regional subsidence. In the study area, this rate has ranged from 0.57 to 1.17 $\mathrm{cm} / \mathrm{yr}(0.23 \mathrm{~cm} / \mathrm{yr}$ from eustatic or general oceanic sea level rise and the remainder from subsidence; Penland et al. 1987). Thus coastal Louisiana represents an appropriate laboratory for studying the response of coastal wetlands to high rates of sea level rise (Day and Templet 1989).

We experimented with the CELSS model to study the effects on the study area of the projected higher rates of sea level rise. Figure $13 \mathrm{~b}$ and Table 2 show the results for rates of 
eustatic sea level rise of 0.46 and 1.67 $\mathrm{cm} / \mathrm{yr}(1.03$ to 1.63 and 2.24 to 2.84 $\mathrm{cm} / \mathrm{yr}$ apparent rates including subsidence) starting in model year 1983.

The results were somewhat surprising. Doubling the rate of eustatic sea level rise (from 0.23 to $0.46 \mathrm{~cm} / \mathrm{yr}$ ) actually caused a slight net gain in land in the study area $\left(+10 \mathrm{~km}^{2}\right.$, or $0.7 \%$ of the total land area) relative to the base case. We believe this increase occurs because, in the presence of high sediment loads, healthy coastal marshes can keep up with moderate rates of sea level rise. In fact, the entire existing coastal marsh system in Louisiana has developed in the presence of high apparent rates of sea level rise (Day and Templet 1989). If sea level rise rates become high enough, however, the marshes can no longer keep up. The Environmental Protection Agency's higher rate of sea level rise $(1.67 \mathrm{~cm} / \mathrm{yr}$ eustatic, $2.24 \mathrm{~cm} / \mathrm{yr}$ apparent) caused a net loss of land of $19 \mathrm{~km}^{2}$ (or $1.3 \%$ of the total land area).

These results indicate that healthy coastal marshes with adequate sediment inputs may act as a buffer against moderate rates of sea level rise. The marshes build coastal marshland as fast as the sea can rise to inundate it.

Historical scenarios. Two historical scenarios were analyzed. We looked at how the system would have evolved if the original Avoca Island levee had not been built or if neither the levee nor the the post-1956 canals had been built. Results are summarized in Figure 13b and Table 2. These results indicate that both the original levee and the canals had a major effect on the evolution of the system. Results of these runs are not directly comparable with the base case 2033 scenario, because the base case was restarted with actual 1983 data, whereas the historical scenarios had to use model predictions for 1983. Nevertheless, it is clear that the post-1956 canals and the original levee caused increased land loss in the area compared to what would have happened without them.

\section{Conclusions}

The CELSS model simulation of longterm ecosystem changes demonstrates that spatially linked ecological and physical processes can be realistically modeled on modern supercomputers. The results of the CELSS model indicate complex and often counterintuitive behavior that, like the real system, is difficult to summarize. This observation is not surprising, given that the CELSS model trades off generality for realism. The model is most enlightening in its elaboration of the effects of specific cases. Nevertheless, a few general conclusions can be drawn from this modeling exercise.

- Past and future climate variations are important, especially severe deviations from average conditions (i.e., severe droughts, floods, and hurricanes). Random climate variations with no change in the historical trends can cause changes in the region of approximately equal magnitude to that of the human modifications analyzed. A comprehensive, process-based model such as the CELSS model is essential to separate these effects. Projected future climate changes (particularly changes in the predictability of climates) due to global warming can cause major changes in the region.

- Ecological variables, such as primary production, have significant feedback to physical and chemical processes and significantly affect the model's ability to replicate historical changes in ecosystem type distribution.

- Coastal marshes can adapt to future projected higher rates of sea level rise and serve as a buffer against future global sea level rise if the rates are moderate, sediment sources are available, and the marshes remain healthy.

- Past activities in the area that modified the hydrologic and sediment flow patterns, such as canal and levee construction, at critical stages had significant influence on the evolution of the region. Proposed future modifications seem to have smaller effects, partly because they will occur at less critical times in this landscape's evolution.

- Management options in the area can be effective at mitigating the effects of proposed human alterations, but cumulative effects make analysis of individual options in isolation risky. Process-based spatial models such as CELSS may be necessary to incorporate these cumulative effects, to effectively weigh the costs and benefits of major projects, and to design optimal coastal management strategies.

At present, ecosystem models of the size and complexity of the CELSS model are fairly new and expensive to build and run. But as we gain experience, and as supercomputers and parallel processors become more readily available, models of this type will become more practical tools for understanding and managing ecosystems. Future studies might employ parallel computers (e.g., the Connection Machine ${ }^{1}$ or microcomputerbased transputer systems such as TransLink ${ }^{2}$ boards) to radically improve the speed, complexity, and ease of use of spatial ecosystem models.

We are currently applying the CELSS approach at multiple scales to other coastal areas in Louisiana, Maryland, and South Carolina, and we plan to continue to modify, improve, and experiment with the existing model toward the goal of better environmental management. We hope to learn enough from these applications and experiments to allow both scaling up of this approach for global ecosystem modeling to assess the impacts of global climate change and scaling down to assess local effects in more detail.

\section{Acknowledgments}

This research was supported by the US Fish and Wildlife Service in part with funds from the US Army Corps of Engineers under cooperative agreement \#14-16-0009-84-921 titled "Spatial Simulation Modeling of Coastal Wetland Systems for Evaluating Management Alternatives" (E. Pendleton, project officer) and by from the National Science Foundation under project BSR-8906269 titled "Landscape Modeling: The Synthesis

\footnotetext{
${ }^{1}$ Thinking Machine Corp., 215 First Street, Cambridge, MA 02112.

${ }^{2}$ Levco Corp., 6160 Lusk Boulevard, San Diego, CA 92121.
} 
of Ecological Processes Over Large Geographic Regions and Long Time Scales." Computer time on the CRAY supercomputer at the University of Illinois was provided by the National Center for Supercomputer Applications (NCSA) and by an NSF grant on modeling landscape dynamics (D. Jameson, principal investigator). The NCSA staff was extremely helpful in the performance of this research. We thank J. W. Day Jr. for his critical role in the birth and success of this project and for his input on model formulation and evaluation of results, W. Kitchens for getting this project off the ground, T. Ozman, K. Sampey, S. Leibowitz, P. Nepalli, S. Nellore, M. Ahmed, and P. Templet Jr. for their contributions to computer programming and data assembly, and three anonymous reviewers for their helpful comments on earlier drafts of the manuscript.

\section{References cited}

Bahr, L. M., R. Costanza, J. W. Day Jr., S. E. Bayley, C. Neill, S. G. Leibowitz, and J. Fruci. 1983. Ecological characterization of the Mississippi Deltaic Plain Region: a narrative with management recommendations. FWS/OBS$82 / 69$, US Fish and Wildlife Service Division of Biological Service, Washington, DC.

Baumann, R. H., and R. Adams. 1981. The creation and restoration of wetlands by natural processes in the lower Atchafalaya River system: possible conflicts with navigation and flood control management. Pages 1-24 in R. H. Stovall, ed. Proceedings of the Eighth Annual Conference on Wetlands Restoration and Creation. Hillsborough, FL.

Baumann, R. H., J. W. Day Jr., and C. A. Miller. 1984. Mississippi deltaic wetland survival: sedimentation versus coastal submergence. Science 224: 1093-1095.

Botkin, D. B., J. F. Janak, and J. R. Wallis. 1972. Some ecological consequences of a computer model of forest growth. J. Ecol. 60: 849-872.

Cleveland, C. J., C. Neill, and J. W. Day Jr. 1981. The impact of artificial canals on land loss in the Barataria Basin, Louisiana. Pages 425-434 in W. J. Mitsch, R. W. Bosserman, and J. M. Klopatek, eds. Energy and Ecological Modeling. Elsevier, Amsterdam.

Conner, W. H., and J. W. Day Jr., eds. 1987. The ecology of the Barataria Basin, Louisiana: an estuarine profile. US Fish and Wildlife Service biology report 85(7.13).

Costanza, R. 1987a. Social traps and environmental policy. BioScience. 37: 407-412. . 1987b. Simulation modeling on the Macintosh using STELLA. BioScience. 37: 129-132.

1989. Model goodness of fit: a multiple resolution procedure. Ecol. Model. 47: 199-215.
Costanza, R., S. C. Farber, and J. Maxwell. In press. The valuation and management of wetland ecosystems. Ecological Economics.

Costanza, R., C. Neill, S. G. Leibowitz, J. R. Fruci, L. M. Bahr Jr., and J. W. Day Jr. 1983. Ecological models of the Mississippi deltaic plain region: data collection and presentation. FWS/OBS-82/68, US Fish and Wildlife Service, Division of Biological Service, Washington, DC.

Costanza, R., and F. H. Sklar. 1985. Articulation, accuracy, and effectiveness of mathematical models: a review of freshwater wetland applications. Ecol. Model. 27: 45-68.

Costanza, R., F. H. Sklar, M. L. White, and J. W. Day Jr. 1988. A dynamic spatial simulation model of land loss and marsh succession in coastal Louisiana. Page 99-114 in W. J. Mitsch, M. Straskraba, and S. E. Jørgensen, eds. Wetland Modelling. Elsevier, Amsterdam.

Craig, N. J., R. E. Turner, and J. W. Day Jr. 1979. Land loss in coastal Louisiana (U.S.A.) Environ. Manage. 3: 133-144.

Day, J. W. Jr., and P. H. Templet. 1989. Consequences of sea level rise: implications from the Mississippi Delta. Coastal Management 17: 241-257.

Deegan, L. A., H. M. Kennedy, and C. Neill. 1984. Natural factors and human modifications contributing to marshloss in Louisiana's Mississippi River deltaic plain. Environ. Manage. 8: 519-528.

Donnell, B., and J. V. Letter. In press. The Atchafalaya River delta. Report 11. Two dimensional model verification. Waterways Experiment Station, Vicksburg, MS.

Farber, S., and R. Costanza. 1987. The economic value of wetlands system. J. Environ. Manage. 24: 41-51.

Gagliano, S. M., K. J. Meyer-Arendt, and K. M. Wicker. 1981. Land loss in the Mississippi River deltaic plain. Trans. Gulf Coast Assoc. Geol. Soc. 31: 285-300.

Gardner, R. H., W. G. Cale, and R. V. O'Neill. 1982. Robust analysis of aggregation error. Ecology 63: 1771-1779.

Hall, C. A. S., and D. L. DeAngelis. 1985. Models in ecology: paradigms found or paradigms lost? Bulletin of the Ecological Society of America 66: 339-346.

Hopkinson, C. S. 1978. The relation of man and nature in Barataria Basin, Louisiana. Ph.D. dissertation, Louisiana State University, Baton Rouge.

Jørgensen, S. E. 1982. Modelling the eutrophication of shallow lakes. Pages 125-155 in D. O. Logofet and N. K. Luckyanov, eds. Ecosystem Dynamics in Freshwater Wetlands and Shallow Water Bodies. vol 2. UNEP/SCOPE, USSSR Academy of Sciences, Moscow.

Leibowitz, S. 1989. The pattern and process of land loss in coastal Louisiana: a landscape ecological analysis. Ph.D. dissertation, Louisiana State University, Baton Rouge.

Letter, J. V. Jr. 1982. The Atchafalaya River deta: extrapolation of delta growth. Waterways Experiment Station, technical report HL-82-15. Vicksburg, MS.

Levins, R. 1966. The strategy of model building in population biology. Am. Sci. 54: 421431.
Penland, S., K. E. Ramsey, R. A. McBride, T. F. Moslow, and K. A. Westphal. 1987. Relative sea level rise and subsidence in Louisiana and the Gulf of Mexico. Louisiana Geological Survey, Coastal Geology Section, Baton Rouge.

Phipps, R. L. 1979. Simulation of wetland forest vegetation dynamics. Ecol. Model. 7: 257-288.

Potter, G. L., H. W. Ellsaesser, M. C. MacCracken, and F. M. Luther. 1979. Performance of the Lawrence Livermore Laboratory zonal atmospheric model. Pages 852871 in W. L. Gates, ed. Report of the JOC study conference on climate models: performance, intercomparison and sensitivity studies. Global Atmospheric Research Programme Series no. 22, Washington, DC.

Roberts, H. H., R. D. Adams, and R. H. Cunningham. 1980. Evolution of the sanddominated subaerial phase, Atchafalaya Delta, Louisiana. Am Assoc. Pet. Geol. Bull. 64: 264-279.

Scaife, W. W., R. E. Turner, and R. Costanza. 1983. Coastal Louisiana recent land loss and canal impacts. Environ. Manage. 7: 433442.

Schlesinger, M. E., and Z. C. Zhao, 1989. Seasonal climatic changes induced by doubled $\mathrm{CO}_{2}$ as simulated by the OSU atmospheric GCM/mixed-layer ocean model. Journal of Climate 2: 463-499.

Sklar, F. H., R. Costanza, and J. W. Day Jr. 1985. Dynamic spatial simulation modeling of coastal wetland habitat succession. Ecol. Modell. 29: 261-281.

Sklar, F. H., M. L. White, and R. Costanza. In press. The Coastal Ecological Landscape Spatial Simulation (CELSS) model: structure and results for the Atchafalaya/Terrebonne study area. NWRC open file report. US Fish and Wildlife Service, Washington, DC.

Titus, J. G., ed. 1988. Greenhouse effect, sea level rise and coastal wetlands. EPA230-05-86-013, Office of Policy, Planning, and Evaluation, Washington, DC.

Turner, M. G., R. Costanza, and F. H. Sklar. 1989. Methods to evaluate the performance of spatial simulation models. Ecol. Modell. 48: 1-18.

Turner, M. G., R. Costanza, T. M. Springer, and E. P. Odum. 1988. Market and nonmarket values of the Georgia landscape. Environ. Manage. 12: 209-217.

Washington, W. M., and D. L. Williamson. 1977. A description of the NCAR global circulation models. Pages $111-172$ in J. Chang, ed. Methods of Comparative Physics. vol. II. General Circulation Models of the Atmosphere. Academic Press, New York.

Williams, J., R. G. Barry, and W. M. Washington. 1974. Simulation of the atmospheric circulation using the NCAR global circulation model with ice age boundary conditions. Journal of Applied Meteorology 11: $305-$ 317.'

Van Heerden, I. L., and H. H. Roberts. 1980a. The Atchafalaya Delta-Louisiana's new prograding coast. Trans. Gulf Coast Assoc. Geol. Soc. 30: 497-506.

.1980b. The Atchafalaya Delta-rapid progradation along a traditionally retreating coast (South Central Louisiana). Zeitschrift Geomorphologie N.F. 34: 186-201. 